Article

\title{
Sustainable Chitosan-Dialdehyde Cellulose Nanocrystal Film
}

\author{
Cong Gao ${ }^{1,2,3}$, Shuo Wang ${ }^{1,2}$, Baojie Liu ${ }^{1,2}$, Shuangquan Yao ${ }^{1,2}$, Yi Dai ${ }^{4}$, Long Zhou ${ }^{3}$, Chengrong Qin ${ }^{1,2, *}$ \\ and Pedram Fatehi ${ }^{3, *(D)}$
}

1 Department of Light Industrial and Food Engineering, Guangxi University, Nanning 530004, China; cgao4@lakeheadu.ca (C.G.); 2016401003@st.gxu.edu.cn (S.W.); LiuBaojie@st.gxu.edu.cn (B.L.); yaoshuangquan@gxu.edu.cn (S.Y.)

2 Guangxi Key Laboratory of Clean Pulp \& Papermaking and Pollution Control, Nanning 530004, China

3 Chemical Engineering Department, Lakehead University, Thunder Bay, ON P7B 5E1, Canada; lzhou12@lakeheadu.ca

4 School of Chemical Engineering, Guizhou Minzu University, Guiyang 550025, China; Daiyi2020@gzmu.edu.cn

* $\quad$ Correspondence: qinchengrong@gxu.edu.cn (C.Q.); pfatehi@lakeheadu.ca (P.F.); Tel.: +86-077-13237097 (C.Q.); $+1-807-343-8697$ (P.F.)

check for updates

Citation: Gao, C.; Wang, S.; Liu, B.; Yao, S.; Dai, Y.; Zhou, L.; Qin, C.; Fatehi, P. Sustainable Chitosan-Dialdehyde Cellulose Nanocrystal Film. Materials 2021, 14 , 5851. https://doi.org/10.3390/ ma14195851

Academic Editor: Tao-Hsing Chen

Received: 19 August 2021

Accepted: 29 September 2021

Published: 6 October 2021

Publisher's Note: MDPI stays neutral with regard to jurisdictional claims in published maps and institutional affiliations.

Copyright: (c) 2021 by the authors. Licensee MDPI, Basel, Switzerland. This article is an open access article distributed under the terms and conditions of the Creative Commons Attribution (CC BY) license (https:/ / creativecommons.org/licenses/by/ $4.0 /)$.

\begin{abstract}
In this study, we incorporated 2,3-dialdehyde nanocrystalline cellulose (DANC) into chitosan as a reinforcing agent and manufactured biodegradable films with enhanced gas barrier properties. DANC generated via periodate oxidation of cellulose nanocrystal (CNC) was blended at various concentrations with chitosan, and bionanocomposite films were prepared via casting and characterized systematically. The results showed that DANC developed Schiff based bond with chitosan that improved its properties significantly. The addition of DANC dramatically improved the gas barrier performance of the composite film, with water vapor permeability (WVP) value decreasing from $62.94 \mathrm{~g} \cdot \mathrm{mm} \cdot \mathrm{m}^{-2} \cdot \mathrm{atm}^{-1} \cdot \mathrm{day}^{-1}$ to $27.97 \mathrm{~g} \cdot \mathrm{mm} \cdot \mathrm{m}^{-2} \cdot \mathrm{atm}^{-1} \cdot \mathrm{day}^{-1}$ and oxygen permeability (OP) value decreasing from $0.14 \mathrm{~cm}^{3} \cdot \mathrm{mm} \cdot \mathrm{m}^{-2} \cdot \mathrm{day}^{-1} \cdot \mathrm{atm}^{-1}$ to $0.026 \mathrm{~cm}^{3} \cdot \mathrm{mm} \cdot \mathrm{m}^{-2} \cdot \mathrm{day}^{-1} \cdot \mathrm{atm}^{-1}$. Meanwhile, the maximum decomposition temperature $\left(\mathrm{Td}_{\max }\right)$ of the film increased from $286{ }^{\circ} \mathrm{C}$ to $354{ }^{\circ} \mathrm{C}$, and the tensile strength of the film was increased from $23.60 \mathrm{MPa}$ to $41.12 \mathrm{MPa}$ when incorporating $25 \mathrm{wt}$.\% of DANC. In addition, the chitosan/DANC (75/25, wt/wt) films exhibited superior thermal stability, gas barrier, and mechanical strength compared to the chitosan/CNC $(75 / 25, w t / w t)$ film. These results confirm that the DANC and chitosan induced films with improved gas barrier, mechanical, and thermal properties for possible use in film packaging.
\end{abstract}

Keywords: chitosan; nanocrystalline cellulose; bionanocomposite film; barrier properties; mechanical properties

\section{Introduction}

Since the 1950s, over 6.3 billion tons of plastic waste has been generated on Earth, most of which accumulate in the environment [1]. As these plastic materials are not biodegradable, their extensive production has led to the contamination of natural resources, causing serious problems, such as disturbance of the ecological balance, water pollution, and global warming [2]. In recent years, increasing attention has been paid to the development and application of biobased packaging materials derived from renewable sources that are abundant, biodegradable, inexpensive, and release low levels of carbon dioxide [3-5]. Biobased packaging materials can be generated from biodegradable polymers [6,7]. In this regard, significant efforts have been made to efficiently utilize cellulose and chitin, two of the most abundant polysaccharides in nature, for the production of biodegradable and non-toxic packaging materials [8-10].

Chitosan obtained by $\mathrm{N}$-deacetylation of chitin (1,4-linked-2-amino-deoxy- $\beta$-d-glucan, IUPAC), a natural linear polysaccharide [11], has been widely used in various applications because of its safety, biocompatibility, biodegradability, flocculation ability, and excellent 
film-forming ability [12-14]. Chitosan also possesses antifungal activity and wound healing properties, which make it a potentially valuable material in biomedicine [6,15]. Chitosan films have been widely used as food packaging materials to prevent contamination and extend the shelf-life of food products. Despite these excellent properties, the application of chitosan-derived films is limited by their poor gas barrier performance and low thermal stability and mechanical strength.

Cellulose nanocrystal (CNC) can be used in biodegradable packaging materials because of its unique optical, rheological, and mechanical characteristics [16-18]. CNC has a high length-to-width aspect ratio (10 to 100), strong interconnected network structure, high transparency, and high mechanical strength and stiffness, which make it an ideal reinforcement agent for bionanocomposites [19-21]. Recently, a combination of CNC and chitosan has been investigated for the production of bionanocomposite films, and the results have indicated that the mechanical and water vapor barrier properties of chitosan films can be improved by the addition of CNC [22,23]. However, in the absence of any other treatment, CNC faces a major problem in its application as a reinforcing material, where CNC particles tend to agglomerate when mixed with chitosan in solutions [24]. Despite previous attempts [24], CNC is not well dispersed in the chitosan matrix, and the use of CNC in the chitosan film is limited $[25,26]$.

The regioselective oxidation of $\mathrm{CNC}$ by periodate results in the conversion of two secondary hydroxyl groups in the C2 and C3 positions of glucose into aldehyde groups, generating 2,3-dialdehyde nanocrystalline cellulose (DANC) [27-30]. The periodate oxidation expands the application prospects of $\mathrm{CNC}$, especially in combination with high molecular weight nitrogenous compounds, which can form primary $\left(\mathrm{R}_{1}-\mathrm{CH}=\mathrm{NH}\right)$ or secondary $\left(\mathrm{R}_{1}-\mathrm{CH}=\mathrm{N}-\mathrm{R}_{2}\right)$ aldimines and Schiff bases $\left(\mathrm{R}_{1}-\mathrm{CR}_{3}=\mathrm{N}-\mathrm{R}_{2}\right)$ [30]. There are many applications, such as metal ion adsorbents [31], hydrogels [32], and antimicrobial materials [33]. Several efforts have suggested that DANC can be combined with peptides to have a good antibacterial effect, which can prolong the preservation time of food [34,35]. The Schiff base reaction can occur between the reactive aldehyde groups of DANC and the amino group of chitosan, producing stable imine functionalities, thus promoting the compatibility of DANC and chitosan. Moreover, the formation of hydrogen bonds between the two polymers further facilitates their blending. For food packaging applications, gas barrier properties are critical, and fewer studies have focused on the gas barrier properties of DANC and chitosan films.

The primary aim of this study was to develop bionanocomposite films based on chitosan and DANC with improved gas barrier properties, mechanical strength, and thermal stability. To characterize the effect of DANC as a reinforcing agent, the morphological, thermal, mechanical, surface, and gas barrier properties of the films were studied in detail.

\section{Materials and Methods}

\subsection{Materials and Chemicals}

Microcrystalline cellulose (94\%) was purchased from Sinopharm Chemical Reagent Co. Ltd. (Shanghai, China) and used as a raw material. Chitosan (molecule weight $100 \mathrm{~kg} / \mathrm{mol}$ ) with $>95 \%$ deacetylation degree and sodium periodate (ACS reagent grade, $\geq 99.8 \%$ ) were obtained from Aladdin (Zhejiang, China). The other chemicals used herein were all analytical grades and supplied by Sigma-Aldrich, Mississauga, Canada. Deionized water was used in all reactions. Dialysis membrane (molecular weight cut-off of 8000 14,000 $\mathrm{g} / \mathrm{mol}$ ) was obtained from Union Carbide (Texas City, TX, USA).

\subsection{Preparation of DANC Suspension}

$\mathrm{CNC}$ was prepared by sulfuric acid hydrolysis of microcrystalline cellulose as previously described [36]. The CNC suspension was then oxidized using sodium periodate [37]. In this research, $150 \mathrm{~g}$ of CNC suspension (2.50 $\mathrm{g}$ dry weight) was added to a $1000 \mathrm{~mL}$ flask and oxidized with $28 \mathrm{mmol}$ of sodium periodate at $60^{\circ} \mathrm{C}$ for $2 \mathrm{~h}$. The flask was covered with aluminum foil to avoid light exposure. The dialdehyde nanocrystalline cellulose, 
DANC, was then placed into dialysis membranes, dialyzed until the conductivity of the filtrate was less than $2 \mu \mathrm{S} \cdot \mathrm{cm}^{-1}$, and stored at $4{ }^{\circ} \mathrm{C}$. DANC with an aldehyde content of $8.78 \mathrm{mmol} \cdot \mathrm{g}^{-1}$ was obtained. The determination of the aldehyde group content of DANC was based on oxime reaction between the aldehyde group and hydroxylamine hydrochloride, as previously reported $[38,39]$. The carboxylate content of DANC was $0.014 \mathrm{mmol} \cdot \mathrm{g}^{-1}$, as determined via a conductometric titration method, as described in the literature $[40,41]$.

\subsection{Preparation of Chitosan/DANC Composite Films}

Bionanocomposite films were prepared by the casting method. To obtain a $2 \mathrm{wt} . \%$ suspension of chitosan, chitosan powder was dissolved in a $1 \mathrm{wt} . \%$ acetic acid solution at $50{ }^{\circ} \mathrm{C}$ for $30 \mathrm{~min}$ under stirring. The solution was kept at room temperature for $24 \mathrm{~h}$ to stabilize the solution. The suspension was blended with various amounts of DANC (5-50 wt.\%), and the mixture was stirred at 10,000 rpm for 5 min using an Ultra-Turrax mixer (IKA T10, Germany) to ensure full dispersion, degassed, and cast in an acrylic board $(10 \mathrm{~cm} \times 10 \mathrm{~cm})$; the weight of the film was maintained at $25 \mathrm{~g} \cdot \mathrm{m}^{-2}$. The composite film was dried at $40{ }^{\circ} \mathrm{C}$ for $72 \mathrm{~h}$ and then stored at $20^{\circ} \mathrm{C}$ and $50 \%$ relative humidity (RH). A schematic illustration of the reaction route and linking reaction between chitosan and DANC is shown in Scheme 1.

Chitosan<smiles>CC(C)OC1C(CO)OC(C(C)C)C(O)C1N</smiles>

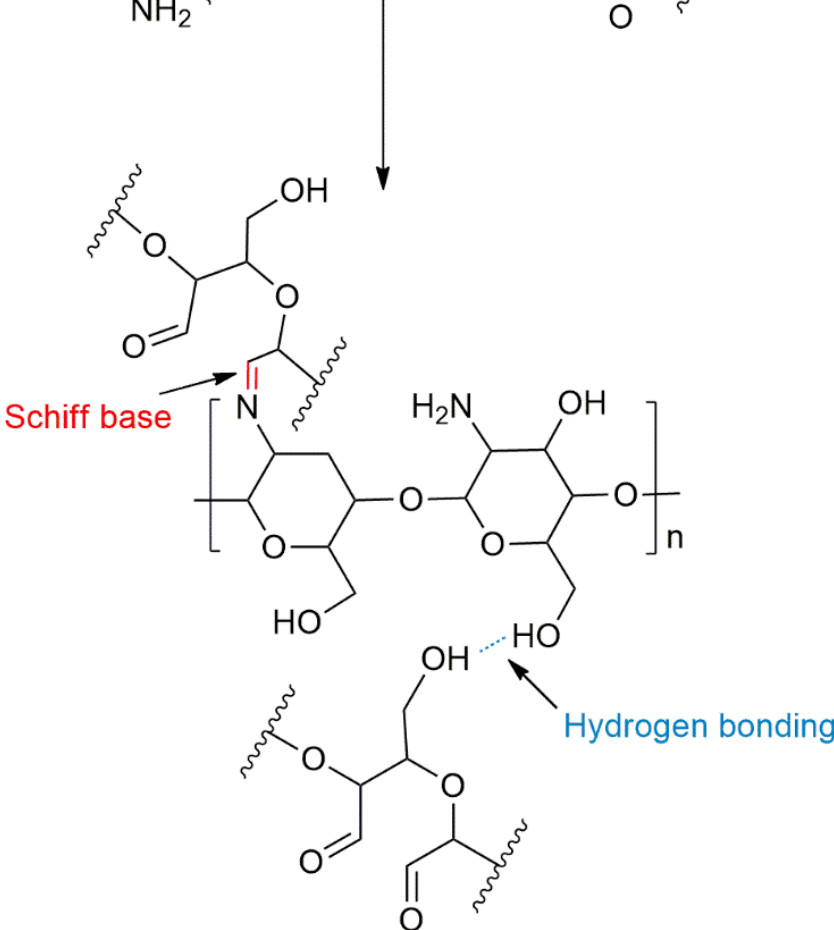

Scheme 1. Schematic of reaction of chitosan and DANC. 


\subsection{Characterization}

\subsubsection{X-ray Diffraction (XRD)}

The XRD analysis was recorded with a Smartlab diffractometer (Rigaku, Akishima, Japan) with a $\mathrm{Cu} K \alpha$ radiation $(\lambda=0.154 \mathrm{~nm}$ ). The operating voltage and current were $40 \mathrm{kV}$

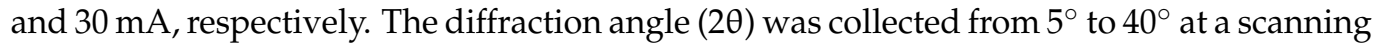
speed of $0.02^{\circ} \mathrm{s}$. Samples were freeze-dried before analysis. The crystallinity index (CrI) of the CNC and DANC samples were calculated using the following Equation (1) [42]:

$$
\mathrm{CrI}=\frac{\mathrm{I}_{002}-\mathrm{I}_{\mathrm{am}}}{\mathrm{I}_{002}}
$$

where $\mathrm{I}_{002}$ represents the intensity of the diffraction peak of the main crystal plane ( $\mathrm{I}_{002}$, $\left.2 \theta=22.8^{\circ}\right)$ and $\mathrm{I}_{\mathrm{am}}$ represents the intensity of the amorphous halo $\left(\mathrm{I}_{\mathrm{am}} 2 \theta=18^{\circ}\right)$, respectively.

\subsubsection{X-ray Photoelectron Spectroscopy (XPS)}

The XPS analysis of the chitosan/DANC (75/25, wt/wt) film was performed using a photoelectron spectrometer (K-Alpha, Thermo fisher scientific, Waltham, USA). In this experiment, $10 \mathrm{mg}$ of dried samples were used directly. Spectra were recorded using a monochromatic $\mathrm{Al} \mathrm{K} \alpha \mathrm{X}$-ray source $(1486.8 \mathrm{eV})$ operating at $15 \mathrm{kV}, 10 \mathrm{~mA}$ with a background pressure of $2 \times 10^{-9} \mathrm{mbar}$. The high-energy resolution spectra were acquired using an energy analyzer operating at a resolution of approximately $0.65 \mathrm{eV}$ and a pass-energy of $187 \mathrm{eV}$. The binding energy scale was calibrated by the $\mathrm{C}$ 1s line of aliphatic carbon, which was set at $284.8 \mathrm{eV}$. Full-spectrum, narrow high-energy resolution spectra, elemental composition, and functional groups were assessed using Avantage software (2020).

\subsubsection{Transmission Electron Microscopy (TEM)}

The morphology of the CNC and DANC samples was obtained by TEM (HT7700, Hitachi, Tokyo, Japan) at an accelerating voltage of $100 \mathrm{kV}$. One drop of the diluted suspension (0.01 wt.\%) was placed on carbon-coated copper grids and dried at room temperature before observation.

\subsubsection{Fourier Transform Infrared Spectroscopy (FTIR)}

FTIR spectra of the resultant films were analyzed using a Tensor II spectrometer (Bruker, Berlin, Germany) in the ATR mode, with spectral width ranging from 4000 to $500 \mathrm{~cm}^{-1}$ at the resolution of $4 \mathrm{~cm}^{-1}$, and 32 scans per sample were conducted.

\subsubsection{Scanning Electron Microscopy (SEM)}

Microstructure analysis of the surface and cross-section of the films was performed by SEM using scanning electron microscopy (F16502, Phenom Pro, Eindhoven, Netherlands). For cross-section imaging, films were quickly frozen in liquid nitrogen to make them brittle. After breaking, the samples were sputtered with gold and were examined with SEM at the accelerating voltage of $5 \mathrm{kV}$.

\subsubsection{Optical Transmittance Measurement}

The optical transmittance of the films was measured at the wavelength range of 300-800 nm using a UV-visible spectrophotometer (Specord 50 Plus, Analytik, Jena, Germany) at the scanning speed of $50 \mathrm{~nm} \cdot \mathrm{s}^{-1}$.

\subsubsection{Thermogravimetric Analysis (TGA)}

For thermogravimetric analysis, samples were weighted at approximately $10 \mathrm{mg}$ in alumina cups and were heated in a pure nitrogen atmosphere (flow rate $20 \mathrm{~mL} \cdot \mathrm{min}^{-1}$ ) from room temperature to $800{ }^{\circ} \mathrm{C}$ at a rate of $10^{\circ} \mathrm{C} \cdot \mathrm{min}^{-1}$ and examined in a synchronous thermal analyzer (Sta449f5, Netzsch, Gerätebau GmbH, Selb, Germany). 


\subsubsection{Thickness and Mechanical Properties}

Film thickness was examined using a digital micrometer (S16502, Frank-PTI, Birkenau, Germany) at ten random positions along with the film, and the average thickness was calculated. Tensile strength (TS) and elongation at break $(\mathrm{Eb})$ tests were performed using a Lorentzen \& Wettre strength tester (LS1, Ametek, Berwyn, PA, USA) with a $100 \mathrm{~N}$ load transducer. Films were cut into $25 \mathrm{~mm} \times 80 \mathrm{~mm}$ strips and tested at a span length of $50 \mathrm{~mm}$. The moving clamp speed was set as $0.5 \mathrm{~mm} \cdot \mathrm{s}^{-1}$. The results were calculated based on at least five measurements.

\subsubsection{Oxygen Permeability (OP)}

The OTR of the films was determined using an oxygen permeability analyzer equipped with a coulometric oxygen sensor (GDP-C, Brugger, Feinmechanik GmbH, Munich, Germany) according to the ISO method (ISO 2556:1974). The films were exposed to $100 \%$ oxygen (purity over $99.999 \%$ ) on one side and a mixture of $98 \%$ nitrogen and $2 \%$ hydrogen on the other. Oxygen permeability (OP) values $\left(\mathrm{cm}^{3} \cdot \mathrm{mm} \cdot \mathrm{m}^{-2} \cdot \mathrm{day}^{-1} \cdot \mathrm{atm}^{-1}\right)$ were determined by multiplying the OTR $\left(\mathrm{cm}^{3} \cdot \mathrm{m}^{-2} \cdot \mathrm{day}^{-1}\right)$ value by the film thickness and dividing it by the partial pressure difference of oxygen $(1 \mathrm{~atm})[11,43]$. The specimen area was $78.4 \mathrm{~cm}^{2}$, and measurements were performed in duplicate at $23{ }^{\circ} \mathrm{C}$.

\subsubsection{Water Vapor Permeability (WVP)}

The water vapor transmission rate (WVTR) was measured in a water vapor permeability tester (TSY-T1, TOYOC, Dongguan, China) using a standard method (ASTM E96). Before testing, films were incubated for $24 \mathrm{~h}$ at $20^{\circ} \mathrm{C}$ and $50 \% \mathrm{RH}$ (as saturated water vapor transmits through films at a certain temperature and humidity); the films were then cut into discs with a diameter of $100 \mathrm{~mm}$, and the WVTR was determined as a decrease in distilled water weight with time $\left(\mathrm{g} \cdot \mathrm{m}^{-2} \cdot \mathrm{day}^{-1}\right)$ according to the formula:

$$
\mathrm{WVTR}=\Delta \mathrm{m} /(\mathrm{A} \times \mathrm{t})
$$

where $\Delta \mathrm{m}$ is distilled water weight difference, $\mathrm{t}$ is the time between two weight measurements, and $\mathrm{A}$ is the exposed film area [44,45].

The WVP of the film was calculated by multiplying the WVTR value by the film thickness and dividing that by the water vapor pressure difference across the film. The unit of WVP is given in $\mathrm{g} \cdot \mathrm{mm} \cdot \mathrm{m}^{-2} \cdot \mathrm{atm}^{-1} \cdot$ day $^{-1}$ [46].

\section{Results and Discussion}

\subsection{Characterization of CNC and DANC}

The aldehyde and carboxylate contents of CNC and DANC samples are provided in Table 1. Due to the periodate oxidation, $8.78 \mathrm{mmol} / \mathrm{g}$ of aldehyde groups were introduced into DANC. Conversely, after periodate oxidation, the carboxylate content of the DANC sample increased from 0.0065 to $0.014 \mathrm{mmol} / \mathrm{g}$. The yield of the CNC preparation process was $67.2 \%$ and the yield of the DANC reaction was $79.2 \%$.

Table 1. Properties of CNC and DANC.

\begin{tabular}{ccc}
\hline Sample & CNC & DANC \\
\hline Aldehyde content, $\mathrm{mmol} / \mathrm{g}$ & - & 8.78 \\
Carboxylate content, mmol/g & 0.0065 & 0.014 \\
CrI, $\%$ & 94.40 & 86.02 \\
yield, $\%$ & 67.2 & 79.2 \\
\hline
\end{tabular}

The morphology and size of CNC and DANC were investigated by TEM, and images are exhibited in Figure 1. No aggregation was found between nanoparticles, and both CNC and DANC exhibited a rod-like morphology with a large aspect ratio. CNC particles had a length of approximately 200 500 nm and a diameter of approximately $15.56 \mathrm{~nm}$ (Figure 1c). 
DANC particles were found to be more uniform, with a smaller size. The diameter of DANC particles was approximately $7.91 \mathrm{~nm}$ (Figure 1d). Similar results were reported in the literature $[47,48]$.
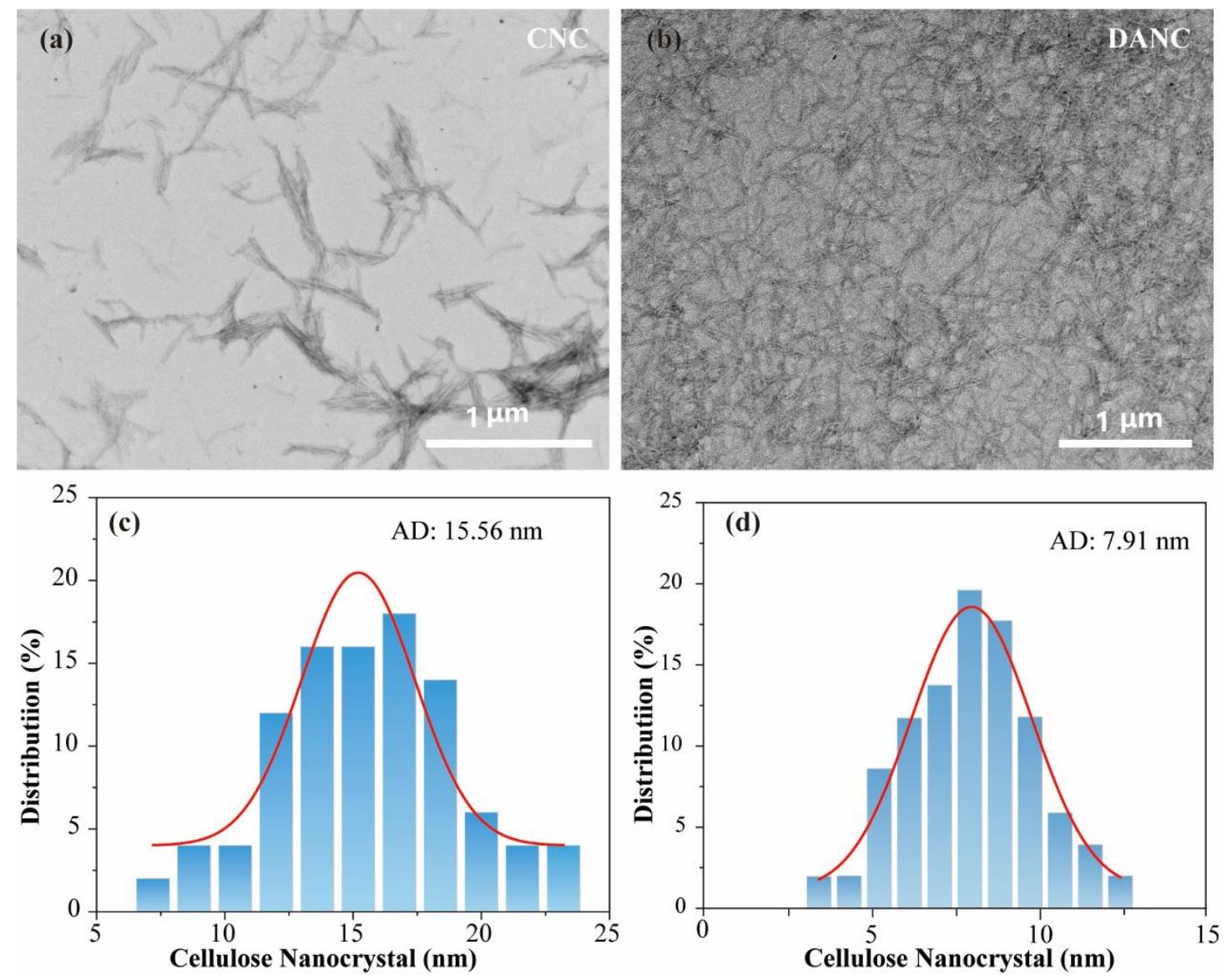

Figure 1. The TEM images of CNC and DANC: (a) CNC, (b) DANC, and the particle size distribution of (c) CNC and (d) DANC.

The FTIR spectra of CNC and DANC are shown in Figure 2a. The positions of characteristic peaks in the CNC and DANC spectrum were similar to those observed in previous studies [39,49]. The appearance of two new absorption bands proved that aldehyde groups were successfully grafted onto DANC; the band of $1730 \mathrm{~cm}^{-1}$ and $892 \mathrm{~cm}^{-1}$ attributed to the $\mathrm{C}=\mathrm{O}$ stretching vibration absorption peak and the hemiacetal bond, respectively $[30,39]$. In addition, the characteristic absorption peak at $1060 \mathrm{~cm}^{-1}$ is the stretching vibration of the primary hydroxyl group, and the intensity of the corresponding absorption peak in DANC is relatively weak, which would indirectly indicate the oxidation between the $\mathrm{CNC}$ molecules. It is noteworthy that the stretching vibration of $\mathrm{O}-\mathrm{H}$ at $3347 \mathrm{~cm}^{-1}$ and aliphatic C-H at $2920 \mathrm{~cm}^{-1}$ of DANC is slightly broader but weaker than those on the CNC spectrum. It has been reported [50] that the hydrogen bonds are arranged axially in the cellulose type I structure, and the periodate oxidation would disrupt the original hydrogen bonding distribution and create many new disordered hydrogen bonds, which would lead to the broadening of the stretching vibration of $\mathrm{O}-\mathrm{H}$.

The X-ray diffraction patterns of CNC and DANC are presented in Figure 2b. The two samples correspond to typical cellulose type I structures with major $2 \theta$ diffraction angles close to $15.1^{\circ}, 16.6^{\circ}$, and $22.5^{\circ}$; these peaks correspond to $101,1 \overline{0} 1$, and 002 crystalline planes, respectively. The crystal structure of DANC did not rearrange after oxidation, which is in agreement with that reported by Varma et al. [51]. The CrI of CNC was $94.40 \%$ (Table 1), which indicated that it had high crystallinity. After the periodate oxidation, 
the main peak of DANC changed into a broad diffraction peak and the CrI of DANC decreased to $86.02 \%$. This can be attributed to the fact that periodate oxidation would result in the ring-opening of the glucopyranose and thus the disruption of the order structure of cellulose molecules [52,53].
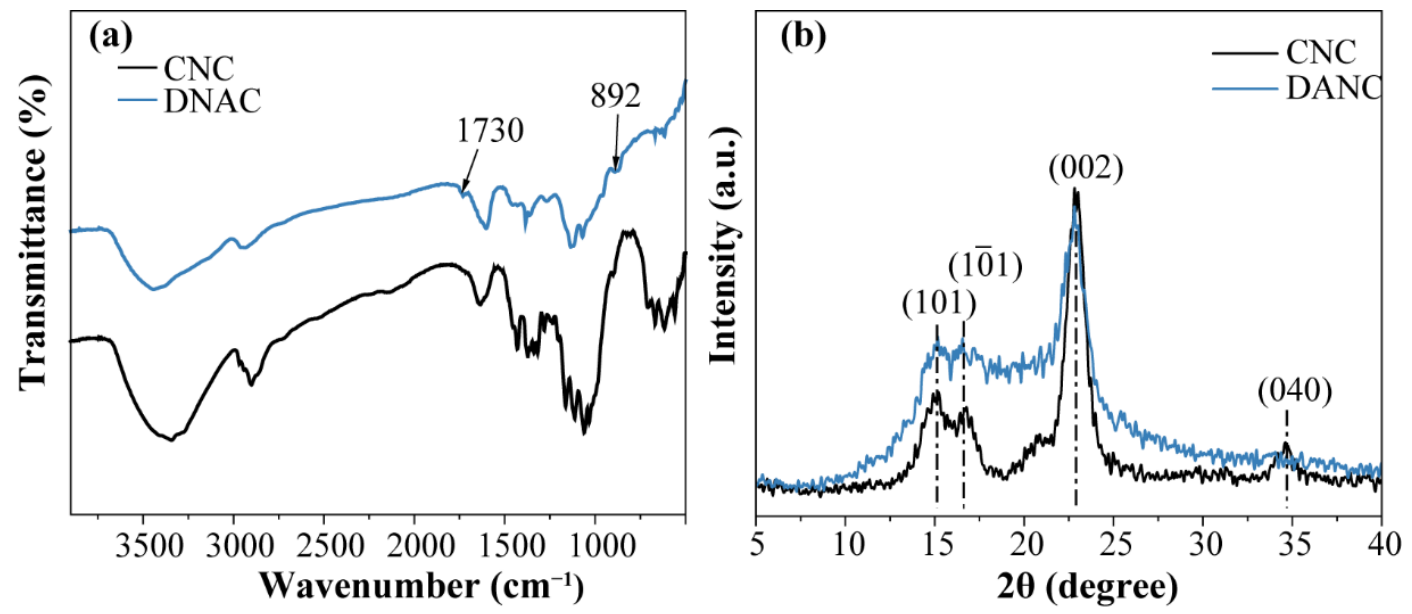

Figure 2. (a) FTIR spectra of CNC and DANC, (b) XRD spectra of CNC and DANC.

\subsection{FTIR Analysis of DANC Containing Film}

FTIR analysis was performed to understand the interaction of DANC and chitosan and assess the effect of DANC incorporation into the chitosan films. Figure 3a shows the FTIR spectra of chitosan/DANC films with different DANC contents, while Figure $3 b$ shows the magnified spectra of the same samples in the range of $1700-1500 \mathrm{~cm}^{-1}$. The characteristic absorption peaks of chitosan at $1644 \mathrm{~cm}^{-1}\left(\mathrm{C}=\mathrm{O}\right.$ stretching in amide I), $1580 \mathrm{~cm}^{-1}$ ( $-\mathrm{NH}_{2}$ bending), and $1380.4 \mathrm{~cm}^{-1}$ (- $\mathrm{CH}_{2}$ bending) were observed [54]. The peaks that appeared at $1150 \mathrm{~cm}^{-1}$ (anti-symmetric stretching of the $\mathrm{C}-\mathrm{O}-\mathrm{C}$ bridge) and $1073 \mathrm{~cm}^{-1}$ (skeletal vibrations involving the $\mathrm{C}-\mathrm{O}$ stretching) correspond to the saccharide structure of chitosan $[55,56]$. The positions of characteristic peaks in the chitosan spectrum were similar to those observed in previous studies [57-59]. A broad absorption peak from 3000 to $3500 \mathrm{~cm}^{-1}$ was mainly associated with the $\mathrm{O}-\mathrm{H}$ stretching vibration and overlapped with $-\mathrm{NH}_{2}$ stretching, whereas a peak at around $2860 \mathrm{~cm}^{-1}$ was attributed to aliphatic C-H stretching vibration [60]. Two characteristic absorption peaks at $1730 \mathrm{~cm}^{-1}$ and $892 \mathrm{~cm}^{-1}$ were observed in the spectrum of DANC films [27,39]. The first one was attributed to $\mathrm{C}=\mathrm{O}$ generated by the periodate oxidation of CNC. The other one was because the periodate oxidation process led to the formation of hemiacetal bonds between the aldehyde groups and neighboring - $\mathrm{OH}[30,45]$. The FTIR spectrum of the pure DANC film revealed absorption peaks at $3440 \mathrm{~cm}^{-1}$ and $2920 \mathrm{~cm}^{-1}$, which were related to $\mathrm{O}-\mathrm{H}$ and aliphatic $\mathrm{C}-\mathrm{H}$ stretching vibrations, respectively.

Compared with the chitosan/CNC film, the addition of DANC caused changes in the FTIR spectra of the chitosan/DANC films. The periodate oxidation resulted in the conversion of two hydroxyl groups in the C2 and C3 positions of glucose into aldehyde groups [30]. A Schiff base bond was formed between the reactive aldehyde groups of DANC and amino groups of chitosan. As DANC content was increased, more aldehyde groups were bound to the amino group of chitosan. Because of the Schiff base reaction, the peak of DANC at $1730 \mathrm{~cm}^{-1}$ (aldehydic carbonyl groups) and $890 \mathrm{~cm}^{-1}$ (hemiacetal bond) vanished after introducing DANC into chitosan. As the content of DANC increased, the intensity of the $-\mathrm{NH}_{2}$ stretching peak at $3450 \mathrm{~cm}^{-1}$ decreased gradually. When the amount of DANC reached $50 \%$, the peak at $3448 \mathrm{~cm}^{-1}$ disappeared. Concurrently, there was a dramatic decrease in the intensity of the absorption band of $-\mathrm{NH}_{2}$ bending at $1580 \mathrm{~cm}^{-1}$ as the content of DANC increased. The peak of $-\mathrm{C}=\mathrm{N}$ stretching vibration at $1640 \mathrm{~cm}^{-1}$ 
formed by the Schiff base reaction overlapped with the $\mathrm{C}=\mathrm{O}$ stretching in the amide I of chitosan. Overall, our results indicated that DANC was successfully introduced into the chitosan matrix. As DANC and chitosan have similar molecular structures, it is expected that the two polymers should have good miscibility and compatibility [61].
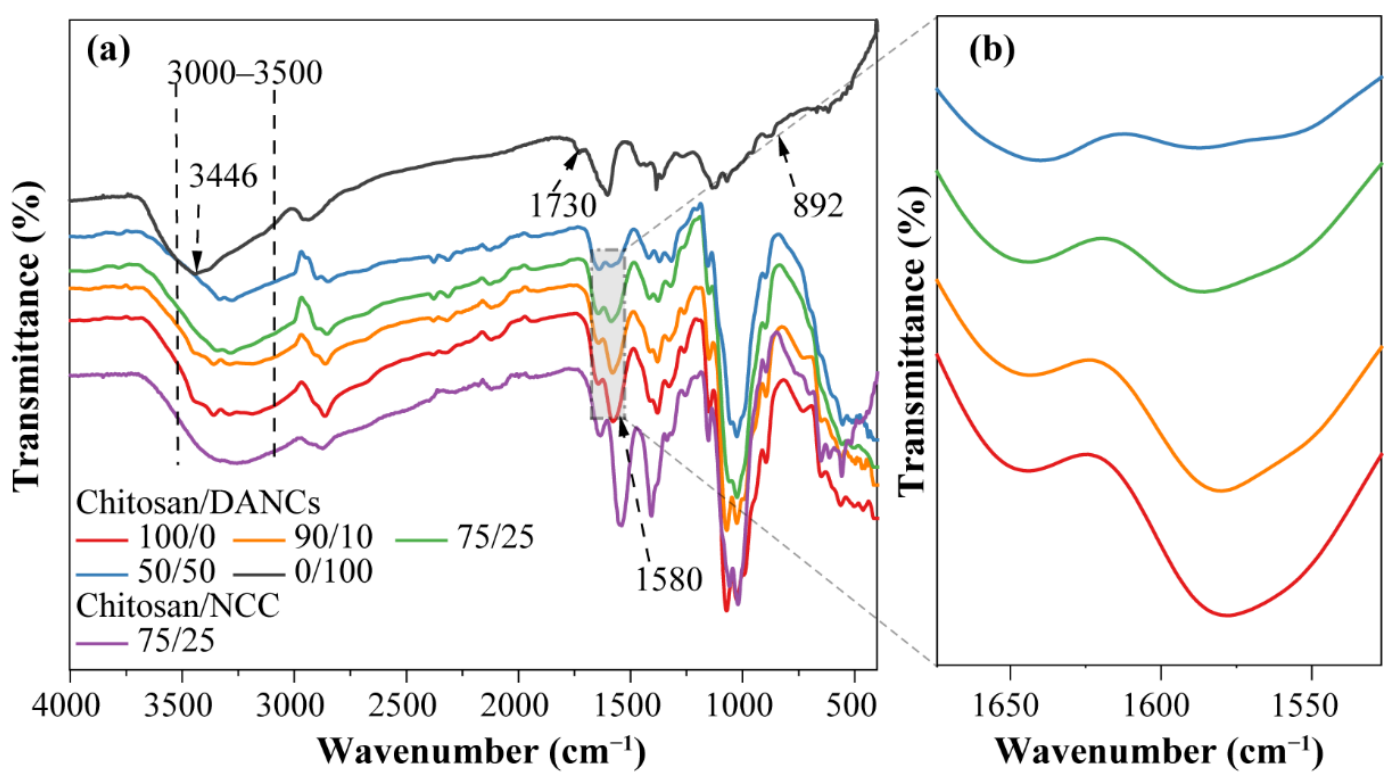

Figure 3. FTIR spectra of chitosan/DANC and chitosan/CNC films, (a) wavenumber range of 450 to $4000 \mathrm{~cm}^{-1}$, (b) magnified wavenumber of $1500-1700 \mathrm{~cm}^{-1}$. Numbers indicate relative content (wt/wt) of chitosan, DANC, and CNC in the films, respectively.

\subsection{XPS Analysis of DANC Containing Film}

To further investigate the surface composition and covalent linkage of the composite films, X-ray photoelectron spectroscopy (XPS) of the films was studied. As shown in Figure $4 \mathrm{a}$, the chitosan/DANC $(75 / 25, \mathrm{wt} / \mathrm{wt})$ film showed two major peaks of $\mathrm{C} 1 \mathrm{~s}$ $(285.2 \mathrm{eV})$ and $\mathrm{O} 1 \mathrm{~s}(532.3 \mathrm{eV})$ as well as a minor peak that can be assigned to $\mathrm{N} 1 \mathrm{~s}(399.5 \mathrm{eV})$ signals. The high-resolution XPS spectra of $\mathrm{C} 1 \mathrm{~s}$ with the fitting data are presented in Figure $4 \mathrm{~b}$. The $\mathrm{C} 1 \mathrm{~s}$ spectrum can be deconvoluted into three sub-peaks. The main peak located at $284.8 \mathrm{eV}$ was attributed to the $\mathrm{C}-\mathrm{C}$ bond [62]. The second peak can be observed at $286.3 \mathrm{eV}$, which indicated the presence of $\mathrm{C}-\mathrm{N}$ and $\mathrm{C}-\mathrm{O}$ bonds [63]. The third peak at $288.8 \mathrm{eV}$ was attributed to $\mathrm{C}=\mathrm{N}$ and $\mathrm{O}=\mathrm{C}-\mathrm{O}$ bonds $[64,65]$. The high-resolution $\mathrm{N} 1 \mathrm{~s}$ spectrum (Figure 4c) was composed of three peaks. The peak at $399.5 \mathrm{eV}$ was attributed to the $\mathrm{C}-\mathrm{N}$ bond. The shoulder peak at $398.8 \mathrm{eV}$ was assigned to the binding energy of the $\mathrm{C}=\mathrm{N}$ bond $[64,66]$, suggesting that a Schiff base reaction (Scheme 1 ) of amino groups and aldehyde groups occurred, which was consistent with the FTIR results (Figure 3). It should be noted that a minor peak was observed at $401.5 \mathrm{eV}$, which could be either an $\mathrm{N}-\mathrm{H}_{2}$ bond in the chitosan, as shown in Scheme 1, or a protonated amine nitrogen $\left(\mathrm{C}=\mathrm{N}-\mathrm{NH}_{3}^{+}\right)[64,67]$. Based on the results, DANC was successfully incorporated into the chitosan matrix via the Schiff base reaction. 


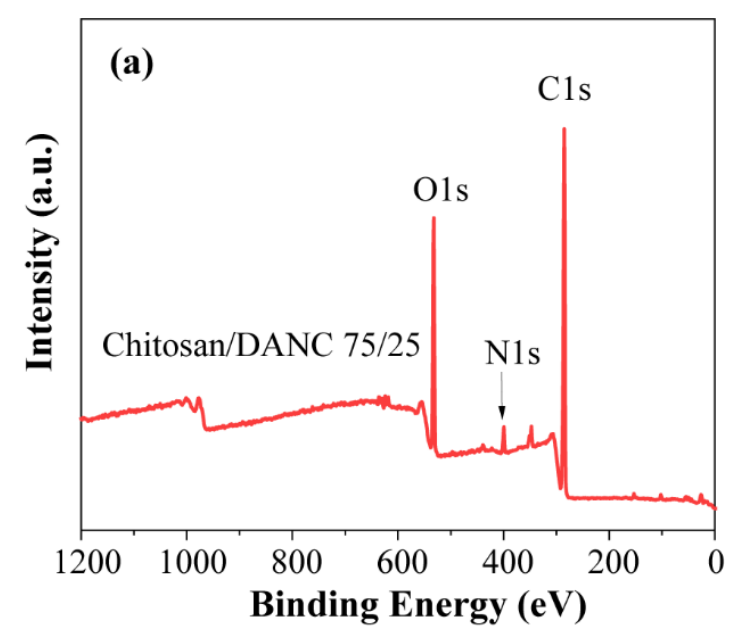

(a)

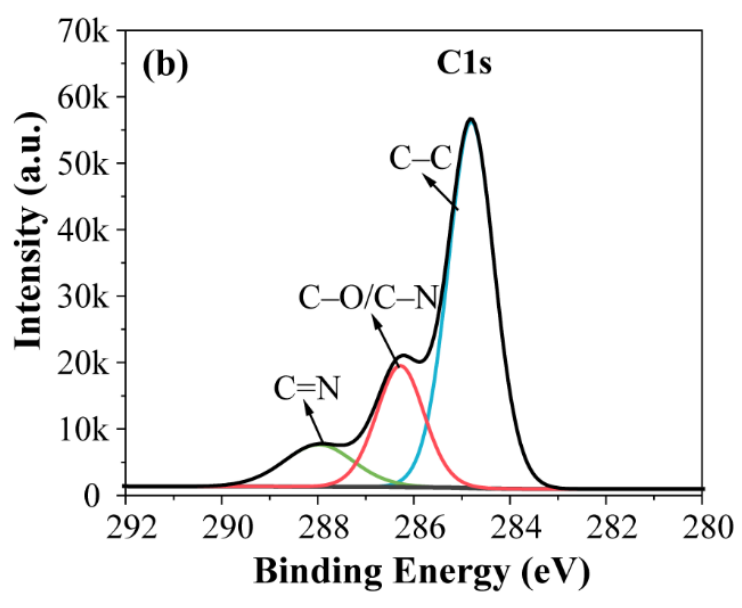

(b)

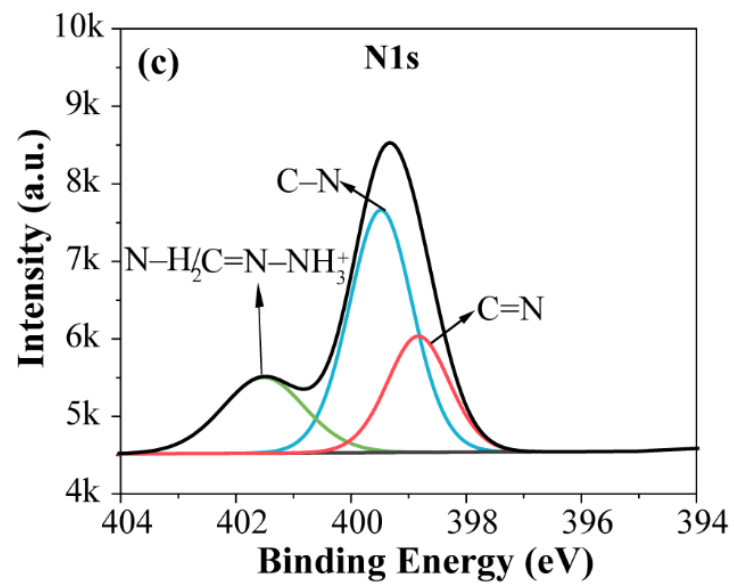

(c)

Figure 4. XPS spectra of chitosan/DANC (75/25, wt/wt) film: (a) full scans, (b) C1s scans, and (c) N1s scans.

\subsection{Thermal Gravimetric Analysis of DANC Containing Film}

The thermal stability of the films was analyzed, and the results are shown in Figure 5a-f. The results of TGA revealed two major weight losses. The initial drop in the temperature range of 50 200 ${ }^{\circ} \mathrm{C}$ was attributed to the evaporation of adsorbed water and acetic acid. Weight losses for chitosan (100/0) and chitosan/DANC (90/10, 75/25 and 50/50, wt/wt) films were $17.31 \%, 17.41 \%, 15.26 \%$, and $16.10 \%$, respectively. The second thermal event resulting in a major weight loss in all films was observed in the temperature range of $200 \sim 400{ }^{\circ} \mathrm{C}$ (Figure 5a), and this trend could be attributed to the fast volatilization of polymer segments due to the thermal scission of the polymer backbone [68]. In an inert atmosphere, there was only one main peak in the thermal degradation curves of pure chitosan film and DANC film, while two main peaks were observed in the curve of chitosan/DANC (90/10, 75/25, 50/50 wt/wt) films. The maximum decomposition temperature (Tdmax) of these steps was determined from the DTG results. The Tdmax for pure chitosan film was $286^{\circ} \mathrm{C}$, while the Tdmax of chitosan/DANC (50/50 wt/wt) film was $354{ }^{\circ} \mathrm{C}$. The Tdmax of chitosan/CNC film was $266^{\circ} \mathrm{C}$ (Figure $5 \mathrm{f}$ ), and the $\mathrm{CNC}$ addition insignificantly affected the thermal behavior of the chitosan films [6,11]. In the chitosan/DANC (90/10, 75/25, wt/wt) films (Figure 5b,c), two degradation steps were observed with Tdmax at 286 and $354{ }^{\circ} \mathrm{C}$. By increasing the DANC content in the chitosan film, the Tdmax of the chitosan/DANC films shifted to higher temperatures, indicating that DANC improved the thermal stability of the film. In this case, the presence of the crystalline structure and great compatibility of chitosan and DANC improved the thermal stability of the chitosan/DANC films. In addition, the Schiff base reactions that 
occurred between DANC and chitosan significantly improved the thermal stability of the composite film. Compared to the pure chitosan film with the maximum weight loss rate of $0.59 \% \cdot{ }^{\circ} \mathrm{C}^{-1}$, the chitosan/DANC $(75 / 25, \mathrm{wt} / \mathrm{wt})$ had a $0.35 \% \cdot{ }^{\circ} \mathrm{C}^{-1}$ weight loss rate. Similar results have been reported in previous studies [69]. In all films, the weight loss tended to become stable gradually at the temperature range of $400 \sim 600{ }^{\circ} \mathrm{C}$. At $600{ }^{\circ} \mathrm{C}$, the residual amounts of the films with 100/0,90/10, 75/25, 50/50, and 75/25 (wt/wt) chitosan/CNC film content were $35.06 \%, 34.21 \%, 35.53 \%, 28.9 \%$, and $38.08 \%$, respectively. Generally, the better degradation performance of chitosan/DANC films was related to the formation of strong hydrogen bonds between the $-\mathrm{OH}$ groups of DANC and the free $-\mathrm{OH}$ groups of chitosan and the Schiff reaction (Scheme 1) [70,71].
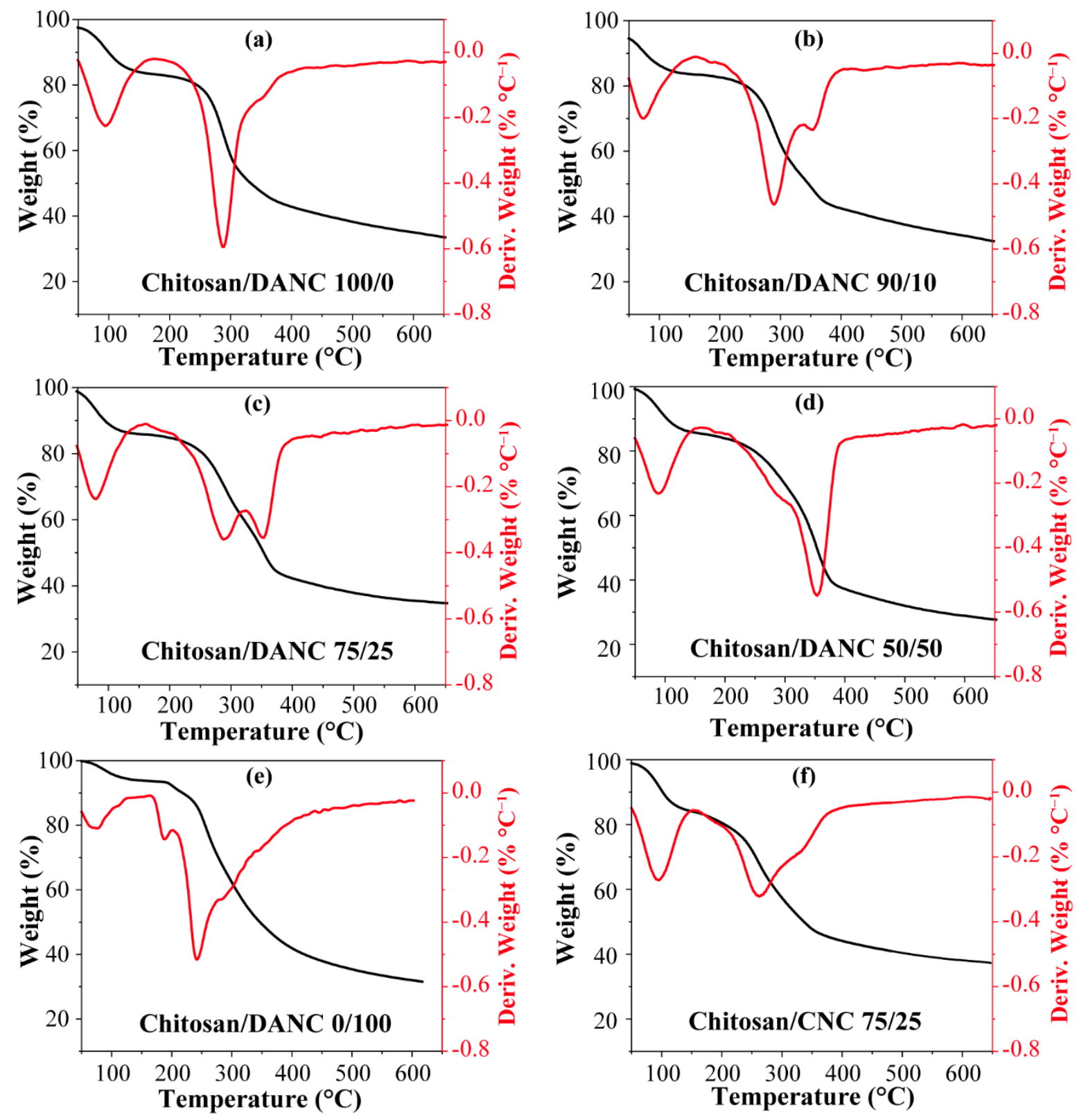

Figure 5. Thermal gravimetric (TG) and derivative thermal gravimetric (DTG) curves for chitosan, chitosan/DANC, and chitosan/CNC films: (a) chitosan/DANC 100/0, (b) chitosan/DANC 90/10, (c) chitosan/DNAC 75/25, (d) chitosan/DANC 50/50, (e) chitosan/DANC 0/100, and (f) chitosan/CNC 75/25. Numbers indicate relative content (wt/wt) of chitosan, $\mathrm{DANC}$, and $\mathrm{CNC}$ in the films, respectively. 


\subsection{Optical Properties of the DANC Containing Films}

Transparency and gloss are important characteristics of films. The optical properties of films are directly related to homogeneity and internal microstructure of the matrix and distribution of DANC in the films [72]. The photographs and optical transmittance curves of chitosan, chitosan/DANC, and chitosan/CNC films are shown in Figure 6a. As discussed, the higher the chitosan content, the higher the transmittance of the film [11,73]. The printed letters "Guangxi" are visible for all sample sets. All composite films have a yellowish appearance. As the DANC content increased, the word "Guangxi" became unclear. The UV-Vis analysis indicated that all chitosan films exhibited very high transparency, with transmittance over $60 \%$ in the visible light range $(380 \sim 740 \mathrm{~nm}$ ) (Figure $6 \mathrm{~b}$ ). The chitosan/DANC films exhibited better light transmission than reported in previous studies, where transparency was reduced to under $40 \%$ at $50 \mathrm{wt} . \%$ cellulose nanofiber inclusion in the chitosan films [74,75]. The addition of DANC to composite films gradually decreased transparency, especially in the range below $600 \mathrm{~nm}$ (Figure 6b). The pure chitosan (100/0) film presented the highest optical transparency of $78.35 \%$ at $500 \mathrm{~nm}$, whereas in the $90 / 10,75 / 25,50 / 50$, and $75 / 25$ chitosan/DANC film, it was $74.01 \%, 72.04 \%, 61.17 \%$, and $72.14 \%$, respectively (Figure $6 \mathrm{c}$ ). This behavior could be related to the slight aggregation of DANC particles in the chitosan matrix and the formation of a Schiff base structure between chitosan and DANC, which would increase the structural density of the film and thus scatter the light more intensely than the pure chitosan and chitosan/CNC films do [76].

(a)

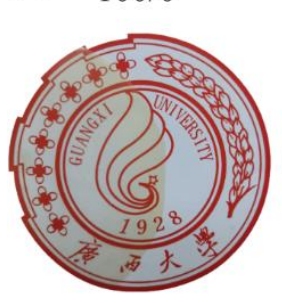

$75 / 25$

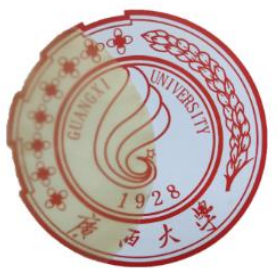

$50 / 50$

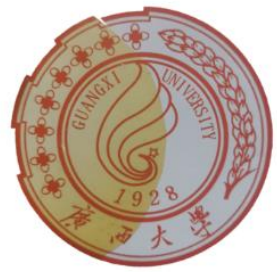

$75 / 25$

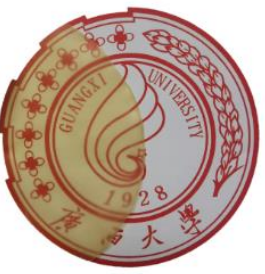

Chitosan /CNC

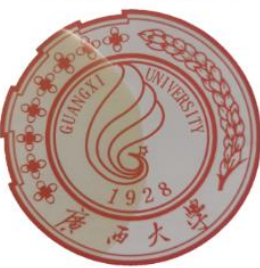

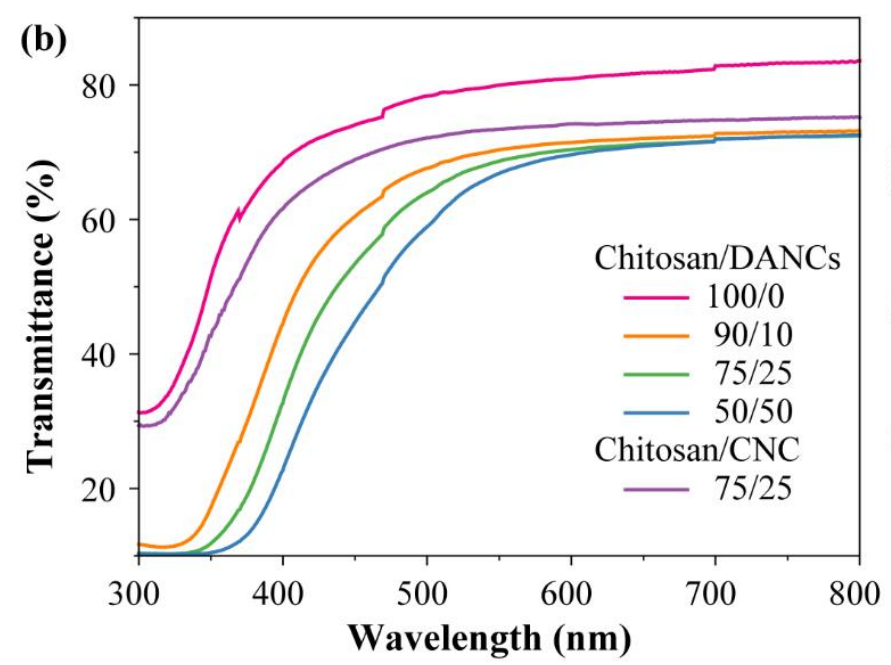

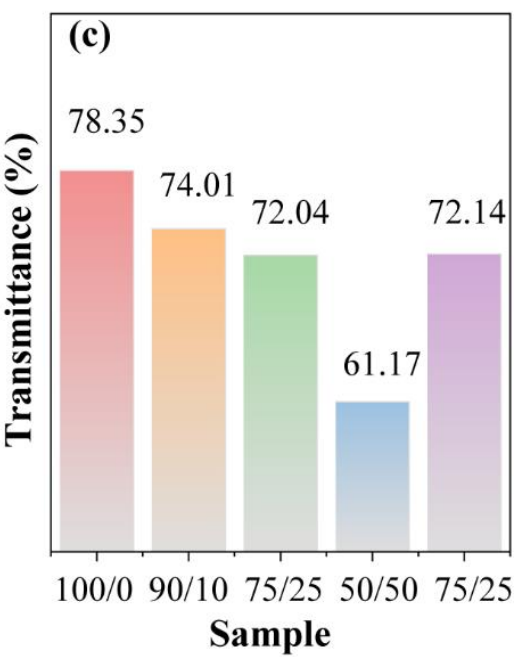

Figure 6. (a) Photograph of composite films; (b) Optical transmittance of composite films with different chitosan, chitosan/DANC, and chitosan/CNC films; (c) Optical transmittance of composite films at $500 \mathrm{~nm}$.

\subsection{Mechanical Properties}

The tensile strength (TS) and elongation at break (Eb) values of chitosan/DANC films are presented in Figure 7, which shows that the TS was increased by the addition of DANC. In other words, the TS, which was $23.60 \mathrm{MPa}$ for the pure chitosan, was increased by the addition of $5,10,15,20,25$, and 50 wt.\% DANC to $28.80,30.02,39.54,36.82,41.12$, 
and $41.06 \mathrm{MPa}$, respectively. The improvement in the tensile strength of the composite film can be attributed to the addition of DANC. The highest TS value obtained was 41.1 MPa with $25 \mathrm{wt}$. $\%$ DANC addition, which was much higher than the $14.2 \mathrm{MPa}$ obtained with the chitosan/CNC (75/25 wt/wt) film (Table 2). Similar results were reported for the other films containing cellulose derivatives. For example, by incorporating $20 \mathrm{wt} . \%$ oxidized cellulose nanofibers into chitosan film, the tensile stress was changed from 10.7 to 18.7 MPa [11]. The increase in the TS for chitosan/DANC films can be attributed to two factors: (1) a large number of active hydroxyl groups in DANC and chitosan molecules, as shown in Scheme 1 [72]; (2) the Schiff base reactions between the aldehyde group of DANC and the amine group of chitosan [24,44,77]. In addition, the reinforcing effect due to efficient stress transfer at the chitosan/DANC interface might lead to the strengthening of the composite film [78]. Such interactions between nanocomposite film components could restrict the segmental mobility of the polymer chains in the vicinity of the nano reinforcement $[11,79]$. The results indicate that DANC can be used for the reinforcement and improvement of the mechanical strength of chitosan-based films, as the formation of good mechanical cohesion is a prerequisite for the development of new composite materials.

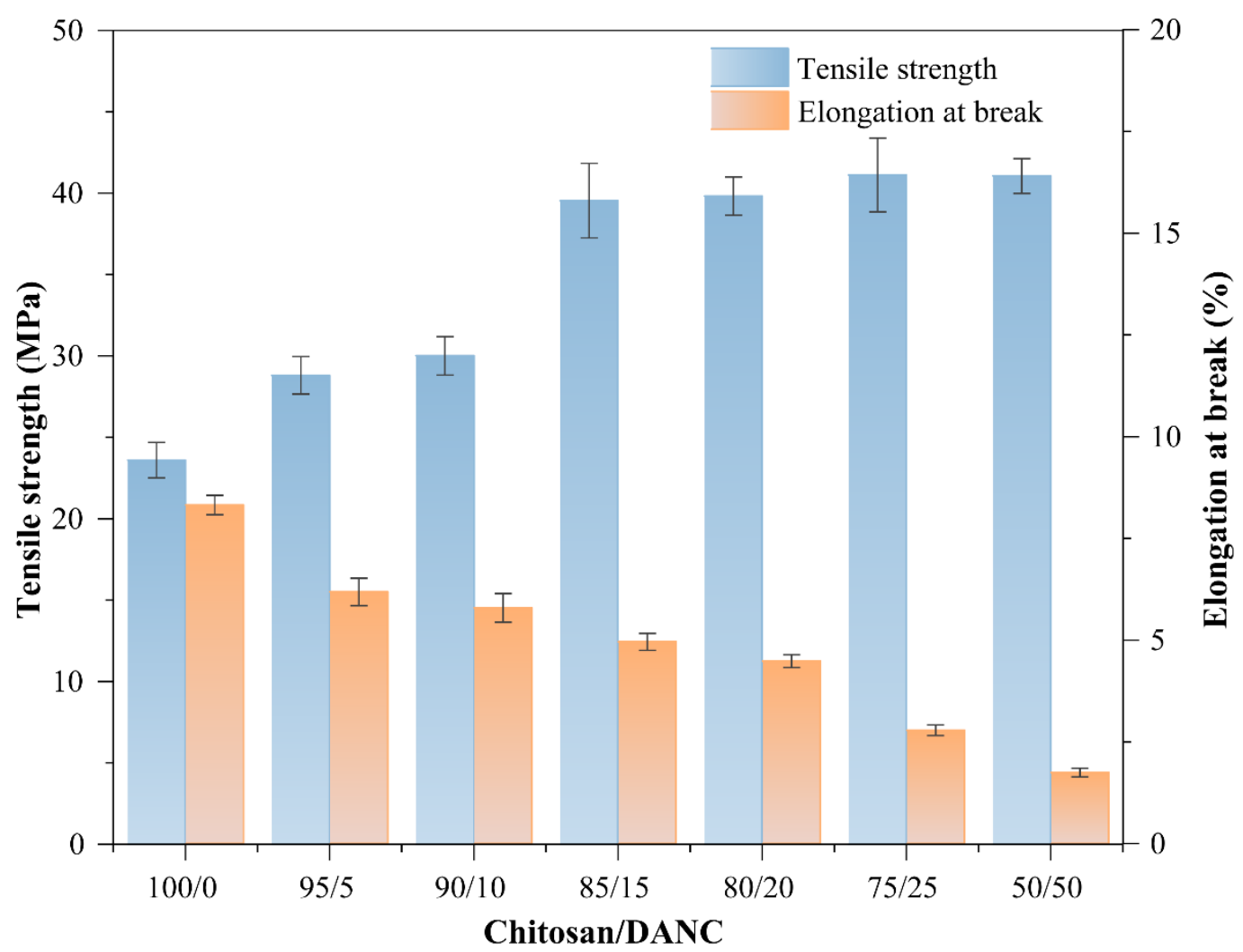

Figure 7. Effect of DANC content on the TS and Eb parameters of chitosan/DANC films. Numbers indicate relative content (wt/wt) of chitosan and DANC in the films, respectively.

The Eb value was found to be $8.32 \%$ for the pure chitosan film and $6.19 \%, 5.79 \%$, $4.96 \%, 4.48 \%, 2.79 \%$, and $1.75 \%$ for $95 / 5,90 / 10,85 / 15,80 / 20,75 / 25$, and $50 / 50$ (wt/wt) chitosan/DANC films, respectively, indicating that the $\mathrm{Eb}$ in films steadily decreased with the addition of DANC to chitosan. The addition of DANC had a negative effect on the brittleness of the composite films. In other studies of chitosan films, a general trend of decreasing Eb value had been observed when the reinforcing material was a nanocellulose based material $[6,11,77]$. The decrease in Eb value can be affected by the volume fraction of the added reinforcing material, the dispersion in the matrix, and the strong interactions between chitosan and DANC restricting the motion of the matrix [23,80,81]. A similar phenomenon was observed in the study of Wang et al. [3]. The addition of DANC has 
significantly increased the tensile strength of the composite film without significantly affecting the flexibility of the composite film.

\subsection{Gas Barrier Properties}

The WVP is one of the most important features of films for their application in the food packaging industry. The WVP is influenced by a diffusion process in which water vapor first condenses and dissolves on the film surface and then droplet water diffuses through the film [82]. Moisture transfer between food and the surrounding atmosphere must be prevented by the films, which is essential for their application in food packaging. The results of the WVP testing in the composite films indicated that DANC caused a reduction in the WVP of the chitosan-based films (Figure 8). The WVP of the pure chitosan film $\left(62.94 \mathrm{~g} \cdot \mathrm{mm} \cdot \mathrm{m}^{-2} \cdot \mathrm{atm}^{-1} \cdot\right.$ day $\left.^{-1}\right)$ was slightly decreased by the addition of $5 \%$ DANC (to $58.51 \mathrm{~g} \cdot \mathrm{mm} \cdot \mathrm{m}^{-2} \cdot \mathrm{atm}^{-1} \cdot \mathrm{day}^{-1}$ ). This may be attributed to the fact that the DANC concentration was too low to form a sufficient amount of hydrogen bonds with the hydrophilic $-\mathrm{OH}$ groups of chitosan to form an effective shield against water. However, a further increase in the DANC content resulted in a dramatic decrease in the WVP (Figure 8a). In this case, the WVP was reduced from $58.51 \mathrm{~g} \cdot \mathrm{mm} \cdot \mathrm{m}^{-2} \cdot \mathrm{atm}^{-1} \cdot \mathrm{day}^{-1}$ in the $95 / 5 \mathrm{wt} / \mathrm{wt}$ film to $27.97 \mathrm{~g} \cdot \mathrm{mm} \cdot \mathrm{m}^{-2} \cdot \mathrm{atm}^{-1} \cdot \mathrm{day}^{-1}$ in the $75 / 25 \mathrm{wt} / \mathrm{wt}$ film. This phenomenon can be attributed to the fact that increasing the incorporation of DANC into the chitosan matrix strengthened the interaction between the two polymers, which slowed moisture diffusion and reduced permeability. It is known that moisture diffuses more easily through amorphous areas of the polymer matrix; therefore, highly crystalline DANC well disperses in the chitosan matrix and probably blocks the moisture transmission [11,16]. In addition, a stable crosslinking system is formed between DANC and the chitosan matrix (Scheme 1), which extends the diffusion path of water molecules within the composite membrane and improves the water vapor barrier properties of the film [83]. The WVTR value was $1063.8 \mathrm{~g} \cdot \mathrm{m}^{-2}$. day ${ }^{-1}$ with $25 \mathrm{wt} . \%$ DANC addition (Figure $8 \mathrm{a}$ ), which was $28 \%$ lower than the $1476.8 \mathrm{~g} \cdot \mathrm{m}^{-2} \cdot$ day $^{-1}$ obtained with the chitosan/CNC $(75 / 25 \mathrm{wt} / \mathrm{wt})$ film (Table 2). The composite films studied in this work show similar results reported for other packaging applications $[82,84,85]$. It was previously reported that films with WVTR in the range of 904-1447 $\mathrm{g} \cdot \mathrm{m}^{-2} \cdot$ day $^{-1}$ were found to be good candidates for the application of moderately exuding wounds [85]. As shown in Figure 8a, the WVRT of chitosan/CNC (80/20, 75/25) films were within the desired range, indicating that chitosan/DANC composite films also have a great potential for application in dressing materials. 

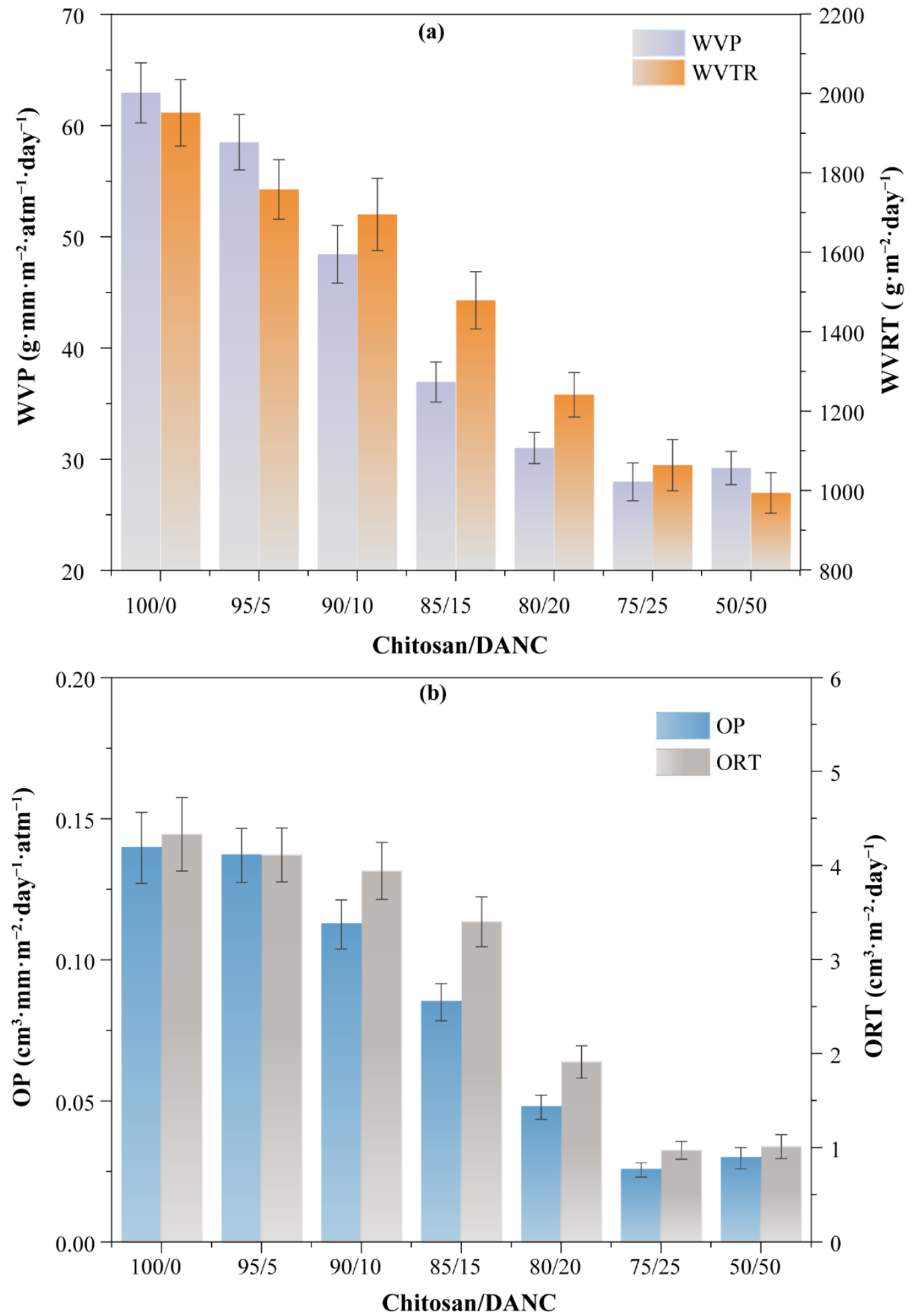

Figure 8. Effect of DANC content on the (a) WVP, WVRT, and (b) OP, ORT value of the chitosan/DANC films. Numbers indicate relative content $(\mathrm{wt} / \mathrm{wt})$ of chitosan and DANC in the films, respectively.

Reduction of the OP, which reflects the amount of oxygen passing through a material in a given period, is crucial for food packaging, as oxygen transmission could lead to product oxidation, which would affect food quality parameters such as odor, color, flavor, and nutrient content [86]. Nanocomposite films have been shown to possess excellent oxygen barrier properties, which can help improve food quality and extend food shelf-life $[30,87,88]$. The 
OP of chitosan-based composite films with various DANC contents demonstrated that oxygen transmission in composite films was significantly reduced with the addition of DANC (Figure $8 \mathrm{~b}$ ). Thus, the pure chitosan film had an OP of $0.14 \mathrm{~cm} \cdot \mathrm{mm} \cdot \mathrm{m}^{-2} \cdot \mathrm{day}^{-1} \cdot \mathrm{atm}^{-1}$, whereas the addition of $5,10,15,20$, and $25 \%$ DANC decreased the OP of the films to 0.13 , $0.11,0.085,0.048$, and $0.025 \mathrm{~cm}^{3} \cdot \mathrm{mm} \cdot \mathrm{m}^{-2} \cdot \mathrm{day}^{-1} \cdot \mathrm{atm}^{-1}$, respectively. A possible reason for such an OP reduction by DANC may be the strong hydrogen bonding between DANC and chitosan molecules, which would lead to the formation of a compact structure of the films, preventing gas permeation [76]. Furthermore, a decrease in the free volume or densification of the network in the polymeric matrix would generate a tortuous path for oxygen, which would consequently decrease permeability [89]. The OTR value of chitosan/DANC films is shown in Figure 8b. Generally, when the OTR of the film was less than $10 \mathrm{~cm}^{3} \cdot \mathrm{m}^{-2}$. day ${ }^{-1}$, it could be regarded as a material with an acceptable oxygen barrier property $[11,90]$. All composite films in this study met this standard. The OTR for the chitosan/DANC $(75 / 25, \mathrm{wt} / \mathrm{wt})$ film was $0.97 \mathrm{~cm}^{3} \cdot \mathrm{m}^{-2}$. day ${ }^{-1}$, which was less than that of the pure chitosan film $\left(4.33 \mathrm{~cm}^{3} \cdot \mathrm{m}^{-2} \cdot\right.$ day $\left.^{-1}\right)$ and the chitosan/CNC $(75 / 25, \mathrm{wt} / \mathrm{wt})$ $\left(3.29 \mathrm{~cm}^{3} \cdot \mathrm{m}^{-2}\right.$. day $\left.{ }^{-1}\right)$ film (Table 2). Based on the oxygen barrier properties of other common commercial packaging film materials, such as polyethylene terephthalate (PET) (110 $\mathrm{cm}^{3} \cdot \mathrm{m}^{-2} \cdot$ day $\left.^{-1}\right)$, polyamideethylene vinyl alcohol (PA-EVOH-PA) $\left(0.5 \mathrm{~cm}^{3} \cdot \mathrm{m}^{-2} \cdot\right.$ day $\left.^{-1}\right)$, and polypropylene-ethylene vinyl alcohol (PP-EVOH-PP) $\left(0.3 \mathrm{~cm}^{3} \cdot \mathrm{m}^{-2} \cdot \mathrm{day}^{-1}\right)$, the oxygen barrier performance of chitosan/DANC films are acceptable [11]. Overall, these results indicate that chitosan/DANC nanocomposite films could be used as a biocompatible food packaging material to protect food from oxidation-induced spoilage.

Table 2. The tensile strength (TS), elongation at break (Eb), WVP, WVRT, OP, and ORT values of chitosan/CNC (75/25, $\mathrm{w} / \mathrm{w}$ ) film.

\begin{tabular}{|c|c|c|c|c|c|c|}
\hline Sample & $\begin{array}{l}\mathrm{TS} \\
\mathrm{MPa}\end{array}$ & $\mathrm{Eb}, \%$ & $\begin{array}{c}\text { WVP, } \\
\mathrm{g} \cdot \mathrm{mm} \cdot \mathrm{m}^{-2} \cdot \text { atm }^{-1} \cdot \text { day }^{-1}\end{array}$ & $\begin{array}{c}\text { WVRT, } \\
\mathrm{g} \cdot \mathrm{m}^{-2} \cdot \text { day }^{-1}\end{array}$ & $\begin{array}{c}\text { OP, } \\
\mathrm{cm}^{3} \cdot \mathrm{mm} \cdot \mathrm{m}^{-2} \cdot \mathrm{day}^{-1} \cdot \mathrm{atm}^{-1}\end{array}$ & $\begin{array}{c}\text { ORT, } \\
\mathrm{cm}^{3} \cdot \mathrm{m}^{-2} \cdot \text { day }^{-1}\end{array}$ \\
\hline $75 / 25$ & 14.2 & 3.05 & 47.64 & 1476.84 & 0.11 & 3.29 \\
\hline
\end{tabular}

\subsection{Morphology of Films}

Based on the experimental results of mechanical properties, gas barrier properties, and light transmission, the dosage of $25 \mathrm{wt} . \%$ was selected as the optimum dosage for both DCNC and CNC. SEM can provide information regarding the distribution of aggregates, the presence of voids, the possible orientation of nanoparticles, and the degree of nanoparticle dispersion within the film [68]. Figure 9 shows the SEM images of surfaces (Figure 9a-d) and cross-sections of a pure chitosan film (Figure 9e-h), a chitosan/DANC film, and a chitosan/CNC film. All chitosan/DANC films had a homogeneous structure without macroscopic pores or cracks, indicating uniformity of the material. The addition of DANC changed the film microstructure (Figure $9 b, c, f, g)$. The images show that DANC was evenly dispersed within the chitosan matrix, and no obvious DANC aggregation was evident, suggesting good compatibility between the two polymers in the matrix [54]. Compared to the pure chitosan film, white dots appeared on the surface of chitosan/DANC films with a DANC content of $10 \%$ (Figure $9 \mathrm{~b}$ ) and $25 \%$ (Figure $9 \mathrm{c}$ ). This was probably due to the transversal sectioning of cellulose crystals [91]. The chitosan/CNC film (Figure 9d) showed an inhomogeneous surface with many irregular protrusions when comparing the chitosan/CNC films to the chitosan/DANC films. Cross-sectional images indicated that the pure chitosan film was smooth and compact (Figure 9e), whereas the incorporation of 25\% DANC resulted in some irregularities, such as multiple ripples and ridges on the surface of the film (Figure 9g). In the cross-sectional image of all samples, the chitosan/CNC film (Figure 9h) was the roughest, and not sufficiently tight in structure. Under these observations, the good distribution and compatibility between DANC and chitosan are prerequisites for improving the mechanical properties of the films. 

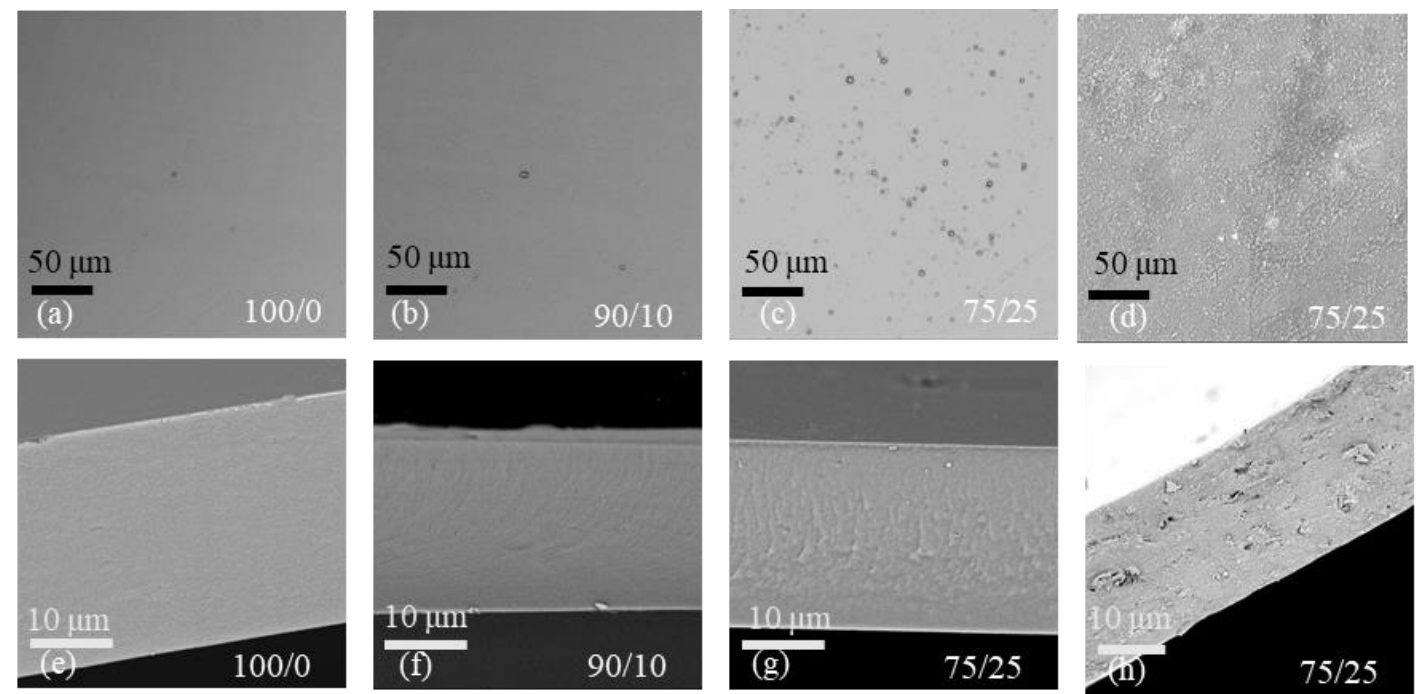

Figure 9. SEM images of chitosan and chitosan/DANC films. (a-d) Surface morphology of pure chitosan (a), chitosan/DANC films (b,c), and chitosan/CNC (d). (e-h) Cross sections of pure chitosan (e), chitosan/DANC (f,g) films, and chitosan/CNC (h). Numbers indicate relative content $(\mathrm{w} / \mathrm{w})$ of chitosan, DANC, and CNC in the films, respectively.

\section{Conclusions}

In this study, DANC was prepared through the periodate oxidation of CNC. DANC was mixed with chitosan at different concentrations as a reinforcing agent, and biocomposite films were prepared by a simple solution-casting method. The FTIR and XPS analyses confirmed that a Schiff base reaction took place between the highly reactive aldehyde group of DANC and the active amino group of chitosan and that DANC was successfully introduced into the chitosan matrix. The results showed that the Tdmax increased from $286^{\circ} \mathrm{C}$ to $354{ }^{\circ} \mathrm{C}$, and the tensile strength was increased from 23.60 MPa to $41.12 \mathrm{MPa}$ when the incorporation of DANC was increased to $25 \mathrm{wt} . \%$ in the chitosan film. Meanwhile, the addition of DANC dramatically improved the gas barrier performance of the composite film, with the WVP value decreasing from $62.94 \mathrm{~g} \cdot \mathrm{mm} \cdot \mathrm{m}^{-2} \cdot \mathrm{atm}^{-1} \cdot \mathrm{day}^{-1}$ to 27.97 $\mathrm{g} \cdot \mathrm{mm} \cdot \mathrm{m}^{-2} \cdot \mathrm{atm}^{-1} \cdot \mathrm{day}^{-1}$ and OP value decreasing from $0.14 \mathrm{~cm}^{3} \cdot \mathrm{mm} \cdot \mathrm{m}^{-2} \cdot \mathrm{day}^{-1} \cdot \mathrm{atm}^{-1}$ to $0.026 \mathrm{~cm}^{3} \cdot \mathrm{mm} \cdot \mathrm{m}^{-2} \cdot \mathrm{day}^{-1} \cdot \mathrm{atm}^{-1}$ when $25 \mathrm{wt} . \%$ DANC was added to the chitosan film. Thus, DANC acted as an excellent reinforcing agent, and it improved the thermal stability and mechanical characteristics of chitosan/DANC composite films, which significantly enhanced the oxygen and water vapor barrier properties of the film. The findings of this study indicated that the incorporation of DANC into chitosan is a feasible and effective approach to producing biodegradable films for food packaging.

Author Contributions: Conceptualization and design, C.G. and C.Q.; methodology and investigation, B.L. and S.W.; formal analysis, C.G., S.Y., L.Z., and Y.D.; supervision, C.Q. and P.F.; supervision and writing-revision, draft preparation, C.G., and C.Q. All authors have read and agreed to the published version of the manuscript.

Funding: The authors would like to thank NSERC, Canada Research Chairs, Canada Foundation for Innovations, and the Northern Ontario Heritage Fund Corporation for funding this research. Additionally, the National Natural Science Foundation of China (21968004) is acknowledged for supporting this research.

Institutional Review Board Statement: Not applicable.

Informed Consent Statement: Not applicable.

Data Availability Statement: The data presented in this study are available on request from the corresponding author. 
Conflicts of Interest: The authors declare no conflict of interest.

\section{References}

1. Geyer, R.; Jambeck, J.R.; Law, K.L. Production, use, and fate of all plastics ever made. Sci. Adv. 2017, 3, e1700782. [CrossRef]

2. Ochando-Pulido, J.M.; Victor-Ortega, M.D.; Martinez-Ferez, A. On the cleaning procedure of a hydrophilic reverse osmosis membrane fouled by secondary-treated olive mill wastewater. Chem. Eng. J. 2015, 260, 142-151. [CrossRef]

3. Wang, H.; Gong, X.; Miao, Y.; Guo, X.; Liu, C.; Fan, Y.-Y.; Zhang, J.; Niu, B.; Li, W. Preparation and characterization of multilayer films composed of chitosan, sodium alginate and carboxymethyl chitosan-ZnO nanoparticles. Food Chem. 2019, 283, 397-403. [CrossRef] [PubMed]

4. Turalija, M.; Bischof, S.; Budimir, A.; Gaan, S. Antimicrobial PLA films from environment friendly additives. Compos. Part B-Eng. 2016, 102, 94-99. [CrossRef]

5. Kuswandi, B. Environmental friendly food nano-packaging. Environ. Chem. Lett. 2017, 15, 205-221. [CrossRef]

6. Pinem, M.P.; Wardhono, E.Y.; Nadaud, F.; Clausse, D.; Saleh, K.; Guenin, E. Nanofluid to Nanocomposite Film: Chitosan and Cellulose-Based Edible Packaging. Nanomaterials 2020, 10, 660. [CrossRef] [PubMed]

7. Guo, J.; Ge, L.; Li, X.; Mu, C.; Li, D. Periodate oxidation of xanthan gum and its crosslinking effects on gelatin-based edible films. Food Hydrocoll. 2014, 39, 243-250. [CrossRef]

8. Thongsomboon, W.; Serra, D.O.; Possling, A.; Hadjineophytou, C.; Hengge, R.; Cegelski, L. Phosphoethanolamine cellulose: A naturally produced chemically modified cellulose. Science 2018, 359, 334-338. [CrossRef]

9. Kaushik, M.; Moores, A. Review: Nanocelluloses as versatile supports for metal nanoparticles and their applications in catalysis. Green Chem. 2016, 18, 622-637. [CrossRef]

10. Zhang, H.; Jung, J.; Zhao, Y. Preparation and characterization of cellulose nanocrystals films incorporated with essential oil loaded beta-chitosan beads. Food Hydrocoll. 2017, 69, 164-172. [CrossRef]

11. Soni, B.; Hassan, E.B.; Schilling, M.W.; Mahmoud, B. Transparent bionanocomposite films based on chitosan and TEMPO-oxidized cellulose nanofibers with enhanced mechanical and barrier properties. Carbohydr. Polym. 2016, 151, 779-789. [CrossRef] [PubMed]

12. Barros, S.C.; da Silva, A.A.; Costa, D.B.; Costa, C.M.; Lanceros-Mendez, S.; Tamano Maciavello, M.N.; Gomez Ribelles, J.L.; Sentanin, F.; Pawlicka, A.; Silva, M.M. Thermal-mechanical behaviour of chitosan-cellulose derivative thermoreversible hydrogel films. Cellulose 2015, 22, 1911-1929. [CrossRef]

13. Sanchez-Salvador, J.L.; Balea, A.; Monte, M.C.; Blanco, A.; Negro, C. Study of The Reaction Mechanism to Produce NanocelluloseGraft-Chitosan Polymer. Nanomaterials 2018, 8, 883. [CrossRef] [PubMed]

14. Ma, X.; Lv, M.; Anderson, D.P.; Chang, P.R. Natural polysaccharide composites based on modified cellulose spheres and plasticized chitosan matrix. Food Hydrocoll. 2017, 66, 276-285. [CrossRef]

15. Khalil, H.; Saurabh, C.K.; Adnan, A.S.; Fazita, M.R.N.; Syakir, M.I.; Davoudpour, Y.; Rafatullah, M.; Abdullah, C.K.; Haafiz, M.K.M.; Dungani, R. A review on chitosan-cellulose blends and nanocellulose reinforced chitosan biocomposites: Properties and their applications. Carbohydr. Polym. 2016, 150, 216-226. [CrossRef]

16. Wang, J.W.; Gardner, D.J.; Stark, N.M.; Bousfield, D.W.; Tajvidi, M.; Cai, Z.Y. Moisture and Oxygen Barrier Properties of Cellulose Nanomaterial-Based Films. ACS Sustain. Chem. Eng. 2018, 6, 49-70. [CrossRef]

17. Nguyen, H.L.; Hanif, Z.; Park, S.A.; Choi, B.G.; Tran, T.H.; Hwang, D.S.; Park, J.; Hwang, S.Y.; Oh, D.X. Sustainable Boron Nitride Nanosheet-Reinforced Cellulose Nanofiber Composite Film with Oxygen Barrier without the Cost of Color and Cytotoxicity. Polymers 2018, 10, 501. [CrossRef]

18. Kim, T.; Jeon, H.; Jegal, J.; Kim, J.H.; Yang, H.C.; Park, J.; Oh, D.X.; Hwang, S.Y. Trans crystallization behavior and strong reinforcement effect of cellulose nanocrystals on reinforced poly(butylene succinate) nanocomposites. RSC Adv. 2018, 8, 15389-15398. [CrossRef]

19. Yadav, M.; Chiu, F.-C. Cellulose nanocrystals reinforced kappa-carrageenan based UV resistant transparent bionanocomposite films for sustainable packaging applications. Carbohydr. Polym. 2019, 211, 181-194. [CrossRef]

20. Sharma, A.; Thakur, M.; Bhattacharya, M.; Mandal, T.; Goswami, S. Commercial application of cellulose nano-composites-A review. Biotechnol. Rep. 2019, 21, e00316. [CrossRef]

21. Kassab, Z.; Aziz, F.; Hannache, H.; Ben Youcef, H.; El Achaby, M. Improved mechanical properties of k-carrageenan-based nanocomposite films reinforced with cellulose nanocrystals. Int. J. Biol. Macromol. 2019, 123, 1248-1256. [CrossRef]

22. Olivera, S.; Muralidhara, H.B.; Venkatesh, K.; Guna, V.K.; Gopalakrishna, K.; Kumar, K.Y. Potential applications of cellulose and chitosan nanoparticles/composites in wastewater treatment: A review. Carbohydr. Polym. 2016, 153, 600-618. [CrossRef]

23. Azeredo, H.M.C.; Mattoso, L.H.C.; Avena-Bustillos, R.J.; Ceotto Filho, G.; Munford, M.L.; Wood, D.; McHugh, T.H. Nanocellulose Reinforced Chitosan Composite Films as Affected by Nanofiller Loading and Plasticizer Content. J. Food Sci. 2010, 75, N1-N7. [CrossRef] [PubMed]

24. Tian, X.; Yan, D.; Lu, Q.; Jiang, X. Cationic surface modification of nanocrystalline cellulose as reinforcements for preparation of the chitosan-based nanocomposite films. Cellulose 2017, 24, 163-174. [CrossRef]

25. Ferrer, A.; Filpponen, I.; Rodríguez, A.; Laine, J.; Rojas, O.J. Valorization of residual Empty Palm Fruit Bunch Fibers (EPFBF) by microfluidization: Production of nanofibrillated cellulose and EPFBF nanopaper. Bioresour. Technol. 2012, 125, 249-255. [CrossRef] [PubMed] 
26. Khan, A.; Vu, K.D.; Chauve, G.; Bouchard, J.; Riedl, B.; Lacroix, M. Optimization of microfluidization for the homogeneous distribution of cellulose nanocrystals (CNCs) in biopolymeric matrix. Cellulose 2014, 21, 3457-3468. [CrossRef]

27. Liimatainen, H.; Visanko, M.; Sirvio, J.A.; Hormi, O.E.O.; Niinimaki, J. Enhancement of the Nanofibrillation of Wood Cellulose through Sequential Periodate-Chlorite Oxidation. Biomacromolecules 2012, 13, 1592-1597. [CrossRef]

28. Sirviö, J.; Honka, A.; Liimatainen, H.; Niinimäki, J.; Hormi, O. Synthesis of highly cationic water-soluble cellulose derivative and its potential as novel biopolymeric flocculation agent. Carbohydr. Polym. 2011, 86, 266-270. [CrossRef]

29. Sirvio, J.A.; Kolehmainen, A.; Visanko, M.; Liimatainen, H.; Niinimaki, J.; Hormi, O.E.O. Strong, Self-Standing Oxygen Barrier Films from Nanocelluloses Modified with Regioselective Oxidative Treatments. ACS Appl. Mater. Interfaces 2014, 6, 14384-14390. [CrossRef]

30. Plappert, S.F.; Quraishi, S.; Pircher, N.; Mikkonen, K.S.; Veigel, S.; Klinger, K.M.; Potthast, A.; Rosenau, T.; Liebner, F.W. Transparent, Flexible, and Strong 2,3-Dialdehyde Cellulose Films with High Oxygen Barrier Properties. Biomacromolecules 2018, 19, 2969-2978. [CrossRef]

31. Yao, M.; Wang, Z.; Liu, Y.; Yang, G.; Chen, J. Preparation of dialdehyde cellulose graftead graphene oxide composite and its adsorption behavior for heavy metals from aqueous solution. Carbohydr. Polym. 2019, 212, 345-351. [CrossRef]

32. Xu, Q.; Ji, Y.; Sun, Q.; Fu, Y.; Xu, Y.; Jin, L. Fabrication of Cellulose Nanocrystal/Chitosan Hydrogel for Controlled Drug Release. Nanomaterials 2019, 9, 253. [CrossRef] [PubMed]

33. Li, J.P.; Kang, L.; Wang, B.; Chen, K.F.; Tian, X.J.; Ge, Z.; Zeng, J.S.; Xu, J.; Gao, W.H. Controlled Release and Long-Term Antibacterial Activity of Dialdehyde Nanofibrillated Cellulose/Silver Nanoparticle Composites. ACS Sustain. Chem. Eng. 2019, 7, 1146-1158. [CrossRef]

34. Wu, Y.; Li, Q.; Zhang, X.; Li, Y.; Li, B.; Liu, S. Cellulose-based peptidopolysaccharides as cationic antimicrobial package films. Int. J. Biol. Macromol. 2019, 128, 673-680. [CrossRef]

35. George, D.; Maheswari, P.U.; Begum, K.M.M.S. Synergic formulation of onion peel quercetin loaded chitosan-cellulose hydrogel with green zinc oxide nanoparticles towards controlled release, biocompatibility, antimicrobial and anticancer activity. Int. J. Biol. Macromol. 2019, 132, 784-794. [CrossRef]

36. Bondeson, D.; Mathew, A.; Oksman, K. Optimization of the isolation of nanocrystals from microcrystalline cellulose by acid hydrolysis. Cellulose 2006, 13, 171-180. [CrossRef]

37. Liimatainen, H.; Suopajarvi, T.; Sirvio, J.; Hormi, O.; Niinimaki, J. Fabrication of cationic cellulosic nanofibrils through aqueous quaternization pretreatment and their use in colloid aggregation. Carbohydr. Polym. 2014, 103, 187-192. [CrossRef]

38. Lu, T.; Li, Q.; Chen, W.; Yu, H. Composite aerogels based on dialdehyde nanocellulose and collagen for potential applications as wound dressing and tissue engineering scaffold. Compos. Sci. Technol. 2014, 94, 132-138. [CrossRef]

39. Li, H.; Wu, B.; Mu, C.; Lin, W. Concomitant degradation in periodate oxidation of carboxymethyl cellulose. Carbohydr. Polym. 2011, 84, 881-886. [CrossRef]

40. Okita, Y.; Saito, T.; Isogai, A. Entire Surface Oxidation of Various Cellulose Microfibrils by TEMPO-Mediated Oxidation. Biomacromolecules 2010, 11, 1696-1700. [CrossRef]

41. Rattaz, A.; Mishra, S.P.; Chabot, B.; Daneault, C. Cellulose nanofibres by sonocatalysed-TEMPO-oxidation. Cellulose 2011, 18, 585. [CrossRef]

42. Segal, L.C.; Creely, J.; Martin, A.E.J.; Conrad, C.M. An Empirical Method for Estimating the Degree of Crystallinity of Native Cellulose Using the X-Ray Diffractometer. Text. Res. J. 1959, 29, 786-794. [CrossRef]

43. Krochta, J.M.; Baldwin, E.A.; Nisperos-Carriedo, M.O. Edible Coatings and Films to Improve Food Quality; Technomic Publ. Co.: Lancaster, PA, USA, 1994.

44. Noshirvani, N.; Ghanbarzadeh, B.; Gardrat, C.; Rezaei, M.R.; Hashemi, M.; Le Coz, C.; Coma, V. Cinnamon and ginger essential oils to improve antifungal, physical and mechanical properties of chitosan-carboxymethyl cellulose films. Food Hydrocoll. 2017, 70, 36-45. [CrossRef]

45. Chang, W.S.; Chen, H.H. Physical properties of bacterial cellulose composites for wound dressings. Food Hydrocoll. 2016, 53, 75-83. [CrossRef]

46. Woggum, T.; Sirivongpaisal, P.; Wittaya, T. Properties and characteristics of dual-modified rice starch based biodegradable films. Int. J. Biol. Macromol. 2014, 67, 490-502. [CrossRef] [PubMed]

47. Saito, T.; Hirota, M.; Tamura, N.; Kimura, S.; Fukuzumi, H.; Heux, L.; Isogai, A. Individualization of Nano-Sized Plant Cellulose Fibrils by Direct Surface Carboxylation Using TEMPO Catalyst under Neutral Conditions. Biomacromolecules 2009, 10, 1992-1996. [CrossRef] [PubMed]

48. Saito, T.; Nishiyama, Y.; Putaux, J.-L.; Vignon, M.; Isogai, A. Homogeneous suspensions of individualized microfibrils from TEMPO-catalyzed oxidation of native cellulose. Biomacromolecules 2006, 7, 1687-1691. [CrossRef]

49. Luo, H.Z.; Lan, H.; Cha, R.T.; Yu, X.N.; Gao, P.Y.; Zhang, P.; Zhang, C.L.; Han, L.; Jiang, X.Y. Dialdehyde Nanocrystalline Cellulose as Antibiotic Substitutes against Multidrug-Resistant Bacteria. ACS Appl. Mater. Interfaces 2021, 13, 33802-33811. [CrossRef] [PubMed]

50. Nishiyama, Y.; Johnson, G.P.; French, A.D.; Forsyth, V.T.; Langan, P. Neutron Crystallography, Molecular Dynamics, and Quantum Mechanics Studies of the Nature of Hydrogen Bonding in Cellulose I-beta. Biomacromolecules 2008, 9, 3133-3140. [CrossRef] [PubMed] 
51. Varma, A.J.; Chavan, V.B. A Study of Crystallinity Changes in Oxidized Celluloses. Polym. Degrad. Stabil. 1995, 49, $245-250$. [CrossRef]

52. Kim, U.J.; Kuga, S.; Wada, M.; Okano, T.; Kondo, T. Periodate oxidation of crystalline cellulose. Biomacromolecules 2000, 1, 488-492. [CrossRef]

53. Zhang, L.; Yan, P.; Li, Y.; He, X.; Dai, Y.; Tan, Z. Preparation and antibacterial activity of a cellulose-based Schiff base derived from dialdehyde cellulose and L-lysine. Ind. Crop. Prod. 2020, 145, 112126. [CrossRef]

54. Li, Q.; Zhou, J.; Zhang, L. Structure and Properties of the Nanocomposite Films of Chitosan Reinforced with Cellulose Whiskers. J. Polym. Sci. Part B-Polym. Phys. 2009, 47, 1069-1077. [CrossRef]

55. Hassan, E.A.; Hassan, M.L.; Abou-Zeid, R.E.; El-Wakil, N.A. Novel nanofibrillated cellulose/chitosan nanoparticles nanocomposites films and their use for paper coating. Ind. Crop. Prod. 2016, 93, 219-226. [CrossRef]

56. Ridolfi, D.M.; Lemes, A.P.; de Oliveira, S.; Justo, G.Z.; Palladino, M.V.; Duran, N. Electrospun poly(ethylene oxide)/chitosan nanofibers with cellulose nanocrystals as support for cell culture of 3 T3 fibroblasts. Cellulose 2017, 24, 3353-3365. [CrossRef]

57. He, J.-X.; Tan, W.-L.; Han, Q.-M.; Cui, S.-Z.; Shao, W.; Sang, F. Fabrication of silk fibroin/cellulose whiskers-chitosan composite porous scaffolds by layer-by-layer assembly for application in bone tissue engineering. J. Mater. Sci. 2016, 51, 4399-4410. [CrossRef]

58. Ostadhossein, F.; Mahmoudi, N.; Morales-Cid, G.; Tamjid, E.; Javier Navas-Martos, F.; Soriano-Cuadrado, B.; Lopez Paniza, J.M.; Simchi, A. Development of Chitosan/Bacterial Cellulose Composite Films Containing Nanodiamonds as a Potential Flexible Platform for Wound Dressing. Materials 2015, 8, 6401-6418. [CrossRef]

59. Tran, C.D.; Mututuvari, T.M. Cellulose, Chitosan, and Keratin Composite Materials. Controlled Drug Release. Langmuir 2015, 31, 1516-1526. [CrossRef]

60. Yao, S.; Nie, S.; Zhu, H.; Wang, S.; Song, X.; Qin, C. Extraction of hemicellulose by hot water to reduce adsorbable organic halogen formation in chlorine dioxide bleaching of bagasse pulp. Ind. Crop. Prod. 2017, 96, 178-185. [CrossRef]

61. Kim, J.; Cai, Z.; Lee, H.S.; Choi, G.S.; Lee, D.H.; Jo, C. Preparation and characterization of a Bacterial cellulose/Chitosan composite for potential biomedical application. J. Polym. Res. 2011, 18, 739-744. [CrossRef]

62. Yang, X.; Niu, X.; Mo, Z.; Guo, R.; Liu, N.; Zhao, P.; Liu, Z. Perylene-functionalized graphene sheets modified with chitosan for voltammetric discrimination of tryptophan enantiomers. Microchim. Acta 2019, 186, 333. [CrossRef] [PubMed]

63. Barata, J.F.B.; Pinto, R.J.B.; Vaz Serra, V.I.R.C.; Silvestre, A.J.D.; Trindade, T.; Neves, M.G.P.M.S.; Cavaleiro, J.A.S.; Daina, S.; Sadocco, P.; Freire, C.S.R. Fluorescent Bioactive Corrole Grafted-Chitosan Films. Biomacromolecules 2016, 17, 1395-1403. [CrossRef] [PubMed]

64. Zhang, L.; Wang, R.; Liu, R.; Du, X.; Meng, R.; Liu, L.; Yao, J. Rapid capture and visual detection of copper ions in aqueous solutions and biofluids using a novel cellulose-Schiff base. Cellulose 2018, 25, 6947-6961. [CrossRef]

65. Chen, C.; Sun, W.; Lv, H.; Li, H.; Wang, Y.; Wang, P. Spacer arm-facilitated tethering of laccase on magnetic polydopamine nanoparticles for efficient biocatalytic water treatment. Chem. Eng. J. 2018, 350, 949-959. [CrossRef]

66. Bai, X.; Zhang, X.; Gu, H.; Li, F.; Huang, W.; Liang, L.; Ye, Z. Highly selective colorimetric sensing of $\mathrm{Cu}^{2+}$ using a Schiff base derivative immobilized on polyvinyl alcohol microspheres. New J. Chem. 2018, 42, 11682-11688. [CrossRef]

67. Liu, Z.; Wang, H.; Ou, J.; Chen, L.; Ye, M. Construction of hierarchically porous monoliths from covalent organic frameworks (COFs) and their application for bisphenol A removal. J. Hazard. Mater. 2018, 355, 145-153. [CrossRef] [PubMed]

68. Khan, A.; Khan, R.A.; Salmieri, S.; Le Tien, C.; Riedl, B.; Bouchard, J.; Chauve, G.; Tan, V.; Kamal, M.R.; Lacroix, M. Mechanical and barrier properties of nanocrystalline cellulose reinforced chitosan based nanocomposite films. Carbohydr. Polym. 2012, 90, 1601-1608. [CrossRef] [PubMed]

69. Baran, T.; Sargin, I.; Kaya, M.; Mentes, A. Green heterogeneous Pd(II) catalyst produced from chitosan-cellulose micro beads for green synthesis of biaryls. Carbohydr. Polym. 2016, 152, 181-188. [CrossRef] [PubMed]

70. Huq, T.; Salmieri, S.; Khan, A.; Khan, R.A.; Le, T.C.; Riedl, B.; Fraschini, C.; Bouchard, J.; Uribecalderon, J.; Kamal, M.R. Nanocrystalline cellulose (NCC) reinforced alginate based biodegradable nanocomposite film. Carbohydr. Polym. 2012, 90, 1757-1763. [CrossRef]

71. Mehrali, M.; Shirazi, F.S.; Mehrali, M.; Metselaar, H.S.; Kadri, N.A.; Osman, N.A. Dental implants from functionally graded materials. J. Biomed. Mater. Res. Part A 2013, 101, 3046. [CrossRef]

72. Cheng, S.L.; Zhang, Y.P.; Cha, R.T.; Yang, J.L.; Jiang, X.Y. Water-soluble nanocrystalline cellulose films with highly transparent and oxygen barrier properties. Nanoscale 2016, 8, 973-978. [CrossRef]

73. Toivonen, M.S.; Kurki-Suonio, S.; Schacher, F.H.; Hietala, S.; Rojas, O.J.; Ikkala, O. Water-Resistant, Transparent Hybrid Nanopaper by Physical Cross-Linking with Chitosan. Biomacromolecules 2015, 16, 1062-1071. [CrossRef] [PubMed]

74. Fernandes, S.C.M.; Freire, C.S.R.; Silvestre, A.J.D.; Pascoal Neto, C.; Gandini, A.; Berglund, L.A.; Salmén, L. Transparent chitosan films reinforced with a high content of nanofibrillated cellulose. Carbohydr. Polym. 2010, 81, 394-401. [CrossRef]

75. Wu, T.; Farnood, R.; O'Kelly, K.; Chen, B. Mechanical behavior of transparent nanofibrillar cellulose-chitosan nanocomposite films in dry and wet conditions. J. Mech. Behav. Biomed. Mater. 2014, 32, 279-286. [CrossRef]

76. Aulin, C.; Karabulut, E.; Tran, A.; Wagberg, L.; Lindstrom, T. Transparent Nanocellulosic Multilayer Thin Films on Polylactic Acid with Tunable Gas Barrier Properties. ACS Appl. Mater. Interfaces 2013, 5, 7352-7359. [CrossRef]

77. Rubentheren, V.; Ward, T.A.; Chee, C.Y.; Nair, P. Physical and chemical reinforcement of chitosan film using nanocrystalline cellulose and tannic acid. Cellulose 2015, 22, 2529-2541. [CrossRef] 
78. de Mesquita, J.P.; Donnici, C.L.; Pereira, F.V. Biobased Nanocomposites from Layer-by-Layer Assembly of Cellulose Nanowhiskers with Chitosan. Biomacromolecules 2010, 11, 473-480. [CrossRef]

79. Siqueira, G.; Bras, J.; Dufresne, A. Cellulose Whiskers versus Microfibrils: Influence of the Nature of the Nanoparticle and its Surface Functionalization on the Thermal and Mechanical Properties of Nanocomposites. Biomacromolecules 2009, 10, 425-432. [CrossRef]

80. Colom, X.; Carrasco, F.; Pagès, P.; Cañavate, J. Effects of different treatments on the interface of HDPE/lignocellulosic fiber composites. Compos. Sci. Technol. 2003, 63, 161-169. [CrossRef]

81. Fortunati, E.; Armentano, I.; Zhou, Q.; Iannoni, A.; Saino, E.; Visai, L.; Berglund, L.A.; Kenny, J.M. Multifunctional bionanocomposite films of poly(lactic acid), cellulose nanocrystals and silver nanoparticles. Carbohydr. Polym. 2012, 87, 1596-1605. [CrossRef]

82. Cao, Z.; Shen, Z.; Luo, X.; Zhang, H.; Liu, Y.; Cai, N.; Xue, Y.; Yu, F. Citrate-modified maghemite enhanced binding of chitosan coating on cellulose porous membranes for potential application as wound dressing. Carbohydr. Polym. 2017, 166, 320-328. [CrossRef] [PubMed]

83. Quilaqueo Gutiérrez, M.; Echeverría, I.; Ihl, M.; Bifani, V.; Mauri, A.N. Carboxymethylcellulose-montmorillonite nanocomposite films activated with murta (Ugni molinae Turcz) leaves extract. Carbohydr. Polym. 2012, 87, 1495-1502. [CrossRef]

84. Cao, Z.; Luo, X.; Zhang, H.; Fu, Z.; Shen, Z.; Cai, N.; Xue, Y.; Yu, F. A facile and green strategy for the preparation of porous chitosan-coated cellulose composite membranes for potential applications as wound dressing. Cellulose 2016, 23, 1349-1361. [CrossRef]

85. Hashemi Doulabi, A.; Mirzadeh, H.; Imani, M.; Samadi, N. Chitosan/polyethylene glycol fumarate blend film: Physical and antibacterial properties. Carbohydr. Polym. 2013, 92, 48-56. [CrossRef]

86. Fabra, M.J.; Hambleton, A.; Talens, P.; Debeaufort, F.; Chiralt, A. Effect of ferulic acid and $\alpha$-tocopherol antioxidants on properties of sodium caseinate edible films. Food Hydrocoll. 2011, 25, 1441-1447. [CrossRef]

87. Arrieta, M.P.; Fortunati, E.; Dominici, F.; Lopez, J.; Kenny, J.M. Bionanocomposite films based on plasticized PLA-PHB/cellulose nanocrystal blends. Carbohydr. Polym. 2015, 121, 265-275. [CrossRef]

88. Ben Dhieb, F.; Dil, E.J.; Tabatabaei, S.H.; Mighri, F.; Ajji, A. Effect of nanoclay orientation on oxygen barrier properties of LbL nanocomposite coated films. RSC Adv. 2019, 9, 1632-1641. [CrossRef]

89. Aulin, C.; Salazar-Alvarez, G.; Lindström, T. High strength, flexible and transparent nanofibrillated cellulose-nanoclay biohybrid films with tunable oxygen and water vapor permeability. Nanoscale 2012, 4, 6622-6628. [CrossRef]

90. Abdellatief, A.; Welt, B.A. Comparison of New Dynamic Accumulation Method for Measuring Oxygen Transmission Rate of Packaging against the Steady-State Method Described by ASTM D3985. Packag. Technol. Sci. 2013, 26, 281-288. [CrossRef]

91. Samir, M.; Alloin, F.; Dufresne, A. Review of recent research into cellulosic whiskers, their properties and their application in nanocomposite field. Biomacromolecules 2005, 6, 612-626. [CrossRef] 